\title{
Factors Determining 'Burnout' Among Nursing Staffers at a National Hospital in Jamaica
}

\author{
Cortia Bryan-Rose ${ }^{1}$ and Paul Andrew Bourne ${ }^{2 *}$ \\ ${ }^{1}$ College of Health Sciences School of Allied Health and Nursing, University of Technology, Jamaica \\ ${ }^{2}$ Department of Quality Management and Institutional Research, Northern Caribbean University, Jamaica
}

Submission: February 23, 2018; Published: April 06, 2018

*Corresponding author: Paul Andrew Bourne, Department of Quality Management and Institutional Research, Northern Caribbean University, Jamaica, Email: paulbourne1@gmail.com

\section{Abstract}

Introduction: The persistent shortfall in the public health care system in Jamaica has placed tremendous stress on the men and women who work therein. There is no secret that there is a shortfall of nurses at National Hospitals in Jamaica and this is evident from government of Jamaica requests for assistance from the Cuban government to send some of their nurses to aid the nurses-shortfall in some government health institutions.

Objectives: In accordance with the purpose of the study, the research will seek to achieve the following specific research objectives: To determine the level of "burnout" among nurses at a National Hospital in Jamaica; To ascertain the factors contributing to "burnout" among nurses at a National Hospital in Jamaica and To evaluate whether burnout impact on attitude to work among nurses at a National Hospital in Jamaica.

Methods: This study will employ a quantitative research design that is cross-sectional in nature. It is a cross-sectional probability sample survey (i.e., stratified random sampling) of nurses at a National Hospital in Jamaica. A standardized instrument will be used to collect the data for this research. This survey instrument will be used to provide data upon which this study answer the research questions on factors that determine burnout among nurses at a National Hospital in Jamaica. The sample frame will consist of a total of 327 nursing personnel who are employed at the above mentioned institutions for a minimum of 12 months-the sampling frame was obtained by the administrative office of the Spanish Town Hospital. Stratified random sampling will be used to select the nursing personnel from the hospital who will participate in the study.

Findings: Maslach Burnout Inventory for the sampled respondents had a mean score of $68.1 \pm 12.8$. It can be deduced from the mean score for the overall Inventory that burnout among the sampled respondents is very high, with personal fulfillment being high as well as emotional exhaustion. Of all the variables examined in the Pearson's Product Moment Correlations matrix, 7 emerged as having a statistical bivariate relationship with Maslach Burnout Inventory. Direct correlations were found to be with 1) age ( $r=0.144, P=0.027)$, length of time in profession $(\mathrm{r}=0.172, \mathrm{P}=0.011)$, and length of time in current post $(\mathrm{r}=0.170, \mathrm{P}=0.012)$.

Conclusion: The phenomenon of 'burnout' is a reality among nursing personnel at the Spanish Town hospital, and it is one that requires urgent attention. The reality is, nursing personnel feels that there is a high degree of depersonalization and that there is gulf between management and themselves, which is affecting their general burnout. Although the issue of burnout is equally the case among nursing personnel in different geo-political areas, managers have sought to ameliorate some of the challenges in an effort to reduce the difficulty of the job.

Keywords: Burnout; Nursing Professionals; Hospital; Hospital Administration

\section{Introduction}

\section{Background}

In 2014, the human population of Jamaica was approximately 2.711 million estimated by the Statistical Institute of Jamaica with the parish of St. Catherine having $19.1 \%$ of the total population (see Appendix A) [1]. St. Catherine has the second highest number of humans compared to Kingston and St. Andrew (estimated 24.6\%- see Appendix A). The Spanish Town Hospital was opened in June 18, 1952 by Sir Hugh Foote. Spanish Town is the capital of St. Catherine (Figure 1) and the Spanish Town Hospital is in the midst of two rival political gangs (One Order, affiliated to the Jamaica Labor Party; Clansman, affiliated to the
People's National Party), adjacent to many violent prone innercity communities-Thompson Pen, Lakes Pen, Lauriston, Shelter Rock, St. Johns Road, De la Vega City, Lime Tree and De la Vega City (Figure 2).

Violence is nothing new in Spanish Town as this goes back to the 1800s. In 1836, Governor Lionel Smith declared the City of Spanish Town ruin from the attacks of 1655 by the British. The Capital of Kingston was then renamed from Spanish Town to Kingston in 1865 by Sir John Peter Grant Black [2] Buisseret, Sherlock and Campbell) [3]. Health care professionals at the Spanish Town Hospital are frequently called upon to provide 
health care for victims resulting from the rival communities' confrontations. Nurses at the Spanish Town Hospital serve in the following departments: General Surgery; Anesthesiology; General Medicine; Orthopedics; Obstetrics and Gynecology; Ear, Nose and Throat (ENT) Services; Fine needle biopsy; Pediatrics; Neonatal Medicine; Haemodialysis; Laboratory; X-
ray/Ultrasound; Physiotherapy; E.C.G; and Outpatient Clinics. The reality is, the current nurse-staffers are expected to work their entire shift and because of the short staff in the areas they oftentimes carry additional workload including long hours and work in high intensity areas. All of the workload of nurses excludes increased demands in periods of violence.

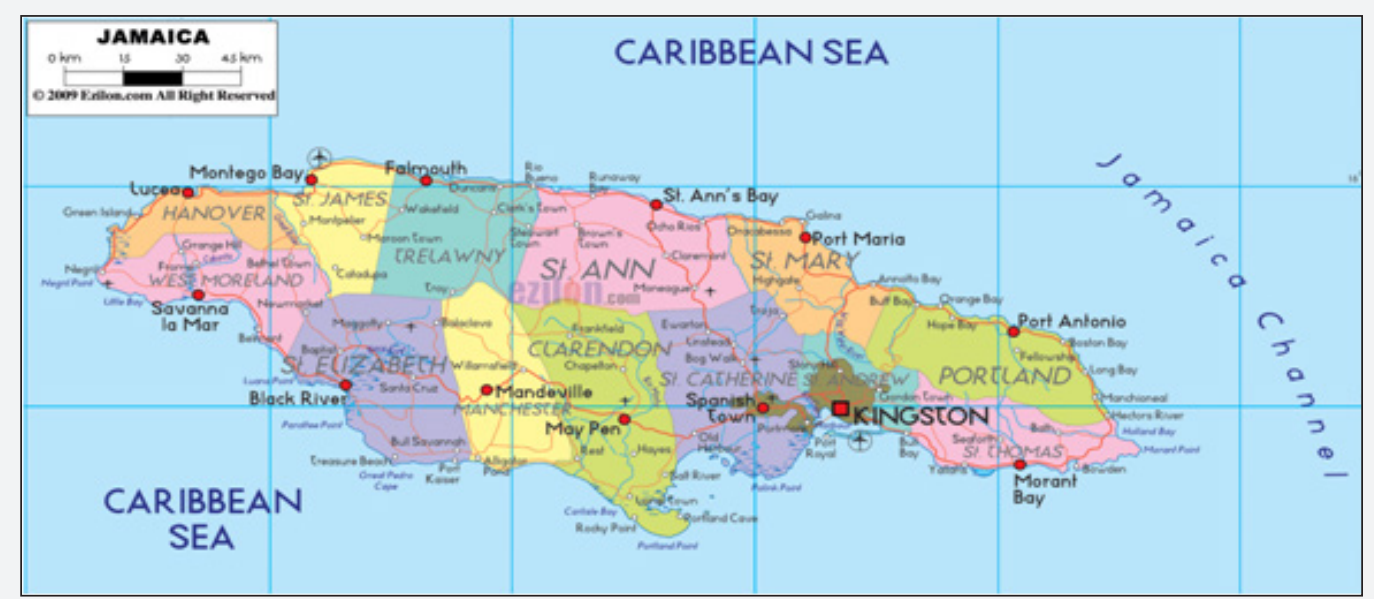

Figure 1: Map of Jamaica by Parishes.

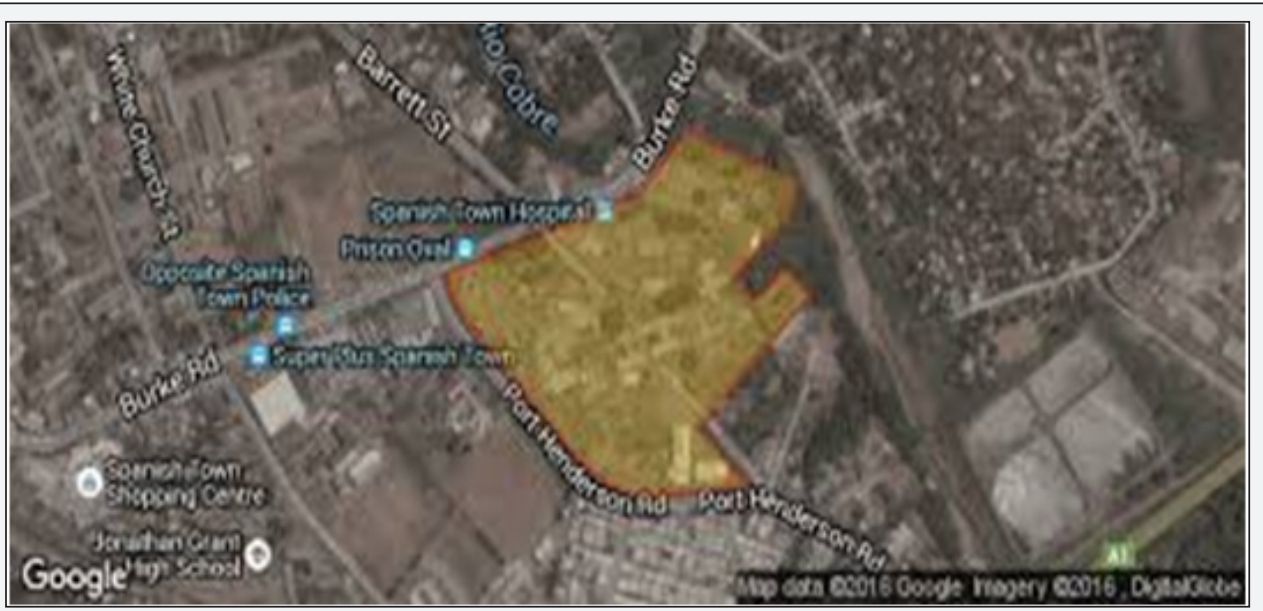

Figure 2 : Map of Spanish Town and location of Spanish Town Hospital.

The Spanish Town Hospital is argued to be the busiest type-B hospital in Jamaica. It serves the entire of St. Catherine population as well as individuals from other parishes. The Spanish Town Hospital has a nursing staff complement of 242 personnel inclusive of registered nurses, registered midwives; enrolled nurses; patient care assistants and theatre technicians. On average, a nurse cares for ten patients on a daily basis. Janet Farr, Nurses Association President of Jamaica, stated that Hospitals in Jamaica have been working with a forty year old cadre that needs to be reviewed. She noted that: Migration of health-care professionals from Jamaica, especially nurses, dates back to the 1950s. It was noted that between 2002 and 2006, more than 1,800 nurses left the region to work abroad. The report at that time stated that there was a shortage of these professionals, which had tangible impact that would compromise the ability of
Jamaica to meet their key health-care services, especially in the areas of disease prevention and care Jamaica Gleaner [4].

Mrs. Far lamented that the ideal nurse patient ratio is one nurse to three patients and that this is not the case in Jamaica as the ratio is far higher in Jamaica Gleaner [4]. This she believes is creating a burnout among medical personnel whom have to work longer hours to meet the needs of the patient-care. In periods of violent clashes between rival political gangs and/or between criminals and police, the Spanish Town Hospital sees an increase in gun related and knife wounds. Morgan [5] opined that the Jamaica's crime problem is bigger than the police and with Spanish Town Hospital being in the midst of violent gangs, is this additional psychological challenge for nurses? The fact is, those cases are outside of the normal ill-health patients, and place the already ailing health sector under more stress. On April 1, 
2008, the government removed user fees from public health care institutions and that translated into a $25.8 \%$ increase in visits to the Spanish Town Hospital followed by decline thereafter as detailed [6-9] while the number of nurses continue to decline because of and not limited to international migration (Table 1) [10-14].

Table 1: Annual Health Care Utilization, Annual Per cent increase and mean Monthly Visits to Spanish Town Hospital.

\begin{tabular}{|c|c|c|c|}
\hline Year & $\begin{array}{c}\text { Annual } \\
\text { Utilization }\end{array}$ & $\%$ & $\begin{array}{c}\text { Mean Monthly } \\
\text { Visits }\end{array}$ \\
\hline 2006 & 44,243 & - & 3,687 \\
\hline 2007 & 44,926 & 1.54 & 3,744 \\
\hline 2008 & 47,707 & 6.19 & 3,976 \\
\hline 2009 & 60,008 & 25.78 & 5,001 \\
\hline 2010 & 47,140 & -21.44 & 3,928 \\
\hline 2011 & 41,854 & -11.21 & 3,488 \\
\hline 2012 & 41,084 & -1.84 & 3,424 \\
\hline 2013 & 42,466 & 3.36 & 3,539 \\
\hline 2014 & 42,028 & -1.03 & 3,502 \\
\hline 2015 & 41,260 & -1.83 & 3,438 \\
\hline
\end{tabular}

\section{Research Objectives}

In accordance with the purpose of the study, the research will seek to achieve the following specific research objectives:

a) To determine the level of "burnout" among nurses at the Spanish Town Hospital, St. Catherine, Jamaica.

b) To ascertain the factors contributing to "burnout" among nurses at the Spanish Town Hospital, St. Catherine, Jamaica.

c) To evaluate whether burnout impact on attitude to work among nurses at the Spanish Town Hospital, St. Catherine, Jamaica.

\section{Research Questions}

Specifically, the study will seek to answer the following research questions:

a) What is the level of "burnout" among nurses at the Spanish Town Hospital, St. Catherine, Jamaica?

b) What are the factors contributing to "burnout" among nurses at the Spanish Town Hospital, St. Catherine, Jamaica?

c) Is there a correlation between burnout and attitude to work among nurses at the Spanish Town Hospital, St. Catherine, Jamaica

\section{Literature Review}

The crisis in the health care sector in Jamaica could be due to many things including 'burnout' among health care professionals, especially nurses, but no empirical study has been done to determine level of 'burnout' and the factors that determine 'burnout'. With the shortage of nurses in the public hospitals [15-17] which is no different from the crisis that exists in other nations Brown [18], nurses have been called upon to work long hours because of the shortage of nurses and this is influencing the quality of care of the human capital of these professionals [19-21]. Historically, there has been a shortfall of health care professionals to meet the demands of the public health care system in Jamaica Jamaica Gleaner, Haye and Alexis, WHO, Carmen and Bench. In keeping with the shortfall of health care professionals in the public health care system in Jamaica, the government, including the Ministry of Health has implemented many programmes to alleviate the problem; but the shortfall continues unabated Lewis [22], Reynolds-Baker [23] Strategies by the Jamaican government to address the shortfall in health care professionals have included the Kingston School of Nursing which offers tuition for nurse personnel, and subsidized retraining courses.

Despite the programmes and initiatives by the government including the Ministry of Health to address the shortfall of health care professionals, particularly nurses, in 2014 the Minister of Health, Fenton Ferguson and Jamaica Observer [24] opined that the public health care system still had a shortfall of those in the sciences including nurses. The brain-drain phenomenon continues to plague the public health care system in Jamaica Lofter [25] Jamaica Gleaner Murphy, et al. [26]. In fact, in 2015, the public health care system in Jamaica lost 200 nurses to international migration Jamaica Observer and this adds to the shortfall of public health care professionals in the system. The 'burnout' phenomenon that continues to affect health care professionals in Jamaica is no different from what obtains in other jurisdictions Patrick and Lavery [27], Azeem, et al. [28] Jennings, et al. [29] Poghosyan, et al. [30], Lasebikan and Oyetunde [31] as well as outside of the health care system Bakker, Demerouti and Sanz-Vergel [32] Leiter, et al. [33] Maslach, et al. [34]. The resultant effect of high stressors placed on nurses has seen increased fatigue, physical illness for example, back pain, frustrations and absenteeism among nurses.

Studies have empirically established that 'burnout' is a feature of high stress jobs including nurses [35-38]. The issue of stress resulting from workload is well documented in the literature [39-41]. In fact, scholars have written on the stressors associated with emotional work which offer some insights, into the psychological challenges of health care professionals Lorenz, et al. [42,43]. To further understand the likely burnout phenomenon among health care professionals, a study by Rushton, Batcheller, Schroeder and Donohue [44] revealed that nurses who are in high intensity settings had greater stress levels than those in low intensity settings. Furthermore, they discovered that burnout among those in high intensity settings were three times more likely to reported burnout, which must be squarely placed into the discourse of nurses, particularly in the context of the volatility of the area in which they work and 
the people who come through the doors of the hospital. The challenge for workers whom are having negative experiences is to decide on whether to leave or remain in the institution. The behavior to leave or remain in a company is not necessarily those for attitude to work as is well documented in the literature [45-49].

Attitude to work, therefore, is influenced by socialization (parental influence) and socioeconomic conditions such as social class, income, occupational status and education, which concurs with the literature [50-52]. A rapidly growing number of people have been experiencing psychological strain at their workplaces. In most industrialized countries, absenteeism, turnover rates increasing, and an increasing number of workers are receiving disablement benefits because of psychological problems. Why is this so? The concept of burn out starts with prolonged stress and demands at work, that may eventually lead to an individual gradually losing energy, functionality and eventually withdrawal and becomes exhausted emotionally. The term "burnout" was first formulated by Herbert Freudenberger, in the 1970s, since then over five thousand books where published on the subject [53]. First defined this phenomenon as "the extinction of motivation or incentive, especially where one's devotion to a cause or relationship fails to produce the desired results." Pines and Aronson defines burn out as "A state of physical, emotional, and mental exhaustion caused by long term involvement in emotionally demanding situations."Defined by the Collins English Dictionary burnout is "a total loss of energy and interest and an inability to function effectively, experienced as a result of excessive demands upon one's resources or chronic overwork."

Now that we understand the idea of burnout, we own need to figure out what are the causes of this. Historically, burnout materializes itself in human service, though not limited to it. The journal for sociology and social welfare defines human service as social services designed to meet human needs or required for maintaining or promoting the overall quality of life of the prospective service populations. Borritz in his $\mathrm{PhD}$ thesis stated that burnout can be caused by several factors, these include a great demand on hiding ones feeling, low possibility of development or even promotion, there is little to no meaning of work, high work pace or roles are not clearly defined. On the other hand, according to, taking into consideration that human service workers are usually giver, they provide services, whether it be giving attention, support, guidance or comfort, they are constantly giving, while the recipient of care, simply receives. This constant giving can put a strain produced through this asymmetrical relationship eventually leading to a deletion in the emotional resources of an individual.

Let us now look at the effects that burnout has on an individual. Though some persons hold the view that stress is a tell tale sign that your life is meaningful and possible successful, this might not always be the case, especially when such stress lead to burnout. Alexandra Michel published an article in the publication of The Association for Psychological Science entitle "Burn out and the brain," stress can cause strain and problems with the brain such as memory, attention, creativity and problemsolving issues. In a study done by AmitaGolkar a psychological scientist, her and her colleagues from the institute in Sweden discovered evidence that burnout can cause alterations to the neural circuits of the brain. This stress of this nature weakens the neurological abilities of an individual to bounce back when faced with negative situations, which in turn causes more stress.

Now that we're having covered the concept and cause and effects of burnout, we will now shift our focus to the some of the individuals usually experiencing this, such as teachers, nurses and administrators. It is important to note that anyone can experience burnout, whether a student or a simple vender on the street corner. The London Metropolitan University, School of Psychology, did a study on the need for achievement, burnout and the feeling of leaving school. The study indicated that the need for achievement lowers the risk of burnout. The study indicated three component of study related burnout, emotional exhaustion, cynicism, and reduced efficacy. Emotional exhaustion promotes cynicism and in turn cynicism promotes reduced efficiency. These three factors can cause a student feeling to leave his or her academic studies. This study also showed that study-related burnout and work-related burnout are basically the same. In a Gleaner article entitled "Students experiencing burnout after GSAT - psychologist" Educational psychologist Kellie-Anne Brown Campbell expressed her concerns for those students starting high school and have already experiencing burnout. She explained that pressure put on students to do well may be affecting them psychologically. This is a clear indicated that burnout is not only limited to working persons but even children.

According to Maria (2015): In 2013, National Health Service (NHS) in England issued a report about nurses leaving the profession due to occupational stress and inability to provide nurse assessed good quality care. The Royal College of nursing revealed that in a survey carried out in 2013 involving 10,000 nurses, $62 \%$ of them contemplated resigning from their job the previous year citing stress. $61 \%$ cited hectic schedules as being a hindrance to providing good quality care and $83 \%$ felt an increase in workload which has seen 5000 nurses leaving the profession in a three-year period (RCN 2013)" (p. 7). Nurses are important to the health sector of every country; however, their jobs can be strenuous. In an Observer article the Nurses Association of Jamaica stated that resignation due to burnout has led to a 1:35 patient to nurse ratio within the health sector indicated that the long hours with a salary that does not match-up, working environment and lack of involvement in decision making, the high risk of unemployment and relationship with one's superiors are some of the cause burnout in healthcare professional. The study went on to point out that research shows nurses believe that the source providing the greatest stress in their occupation 
include, the patient to nurse ration, lack of technical and human resources and the technical and physical conditions I which they work. Reported that issues of burnout have gone un recognize or reported, and may be affecting up to $60 \%$ of family practice provider and one-third of gastroenterologists. This not only limited to these individuals but also younger physician and those individuals doing jobs that have risk procedures. They went on to state that this may lead to suicide, drug and alcohol abuse or suicide, thus indicating the importance that it be addressed.

Teachers are also a part of a profession that demands a lot of them It is agreeable that dealing with one child or two children that is your own is "okay," however, dealing with numerous children, with varying background and personalities can pose a problem. An Australian study done by Howard and Johnson indicated that the ten main causes of stress to teachers were "teaching students who lack motivation; maintaining discipline; time pressures and workload; coping with change; being evaluated by others; dealings with colleagues; self-esteem and status issues; problems dealing with administration/ management; role conflict and ambiguity and poor working conditions". In 2016 the reality of stress and teacher became a deadly reality in Jamaica. In a Gleaner article entitled "Too stressed - Another teacher dies, JTA blames being overworked, expert says not so fast", and English teacher at the Spanish Town High School died after collapsing after a speech she gave at a workshop. Though this has been the third teacher to die in less than a month while on the job, psychologist Dr Leachim Semaj said that teaching "has always been stressful", there putting a link to this death and stress with the proper assessment might basically jumping to conclusion, though this might be so it raises the question as to whether this issue is given the priority that it needs.

Everyone experiences stressful period, children, working adult, even celebrities. But what happens when these gets out of hand? What happens when we are burnout? Do we know the signs to look for in ourselves and the individuals around us? According to an online article entitled (Causes and Prevention of Burnout in Human Services, 2012) some of the sign that we can look out for of burnout are:
a) Withdrawing from responsibilities
b) Isolating self from others
c) Procrastinating, taking longer to get things done
d) Using food, drugs, alcohol to cope
e) Taking out frustrations on others and skipping work or coming in late and leaving early.

The Mayo Clinic's website published an article entitled "Job burnout: How to spot it and take action" which indicated that by asking and answer the following question an individual can identify if he/ she is burnt out: a) Have you become cynical or critical at work?

b) Do you drag yourself to work and have trouble getting started once you arrive?

c) Have you become irritable or impatient with coworkers, customers or clients?

d) Do you lack the energy to be consistently productive?

e) Do you lack satisfaction from your achievements?

f) Do you feel disillusioned about your job?

g) Are you using food, drugs or alcohol to feel better or to simply not feel?

h) Have your sleep habits or appetite changed?

i) Are you troubled by unexplained headaches, backaches or other physical complaints?

The article indicated that if the answer you give to all these questions is yes, then you might be experiencing a job burnout.

Maria [54] postulated that: Burnout is a problem in nursing. These studies and others indicate the prevalence of burnout in the nursing profession. Burnout has a negative impact on the performance of an individual [42]. For nurses, this is crucial information as this directly puts patients' wellbeing and lives in danger as well as going against the code of ethics for nurses. Some of the elements in this code require nurses to: Advocate for health promotion and safety of patients; Develop own competence throughout their practice as well as being mindful of own health; Active participation and contribution to nursing research and development; Collaborate with others in the health care team to promote health and safety of patients (International Council of Nurses 2015). How can nurses experiencing burnout be able to actively participate in health promotion and provide good quality care? How can nurses who are struggling with emotional exhaustion and depersonalization be able to cater to the emotional wellbeing of others? These are all important questions that should be addressed Maria.

The issue of burnout among health care professionals is well documented in the literature and some potent questions were asked by Maria as they would answer questions relating to performance of these people, and the quality of health care they deliver to patients. To answer that question Maria and other researcher have sought to employ Maslach burnout inventory Lorenz, Benatti, and Sabino. Maslach had constructed an index to assess burnout and this is categorized into three dimensions. These are: emotional exhaustion; depersonalization and efficacy. A part of the rationale for this index is to capture the wellbeing of people, quality of life and quality of care provided following the experience of burnout. From a sample of 667 Canadian nurses, Leiter and Maslach [55] found that some of sampled people's working lives account for their burnout, and that this resulted in job separation (or turnover). Burnout among nurses 
was not only found to be associated with job separation or worker retention, it was also found to be correlated with high infection rates, which was caused by heavy workload including heavy patient care delivery [56]. In fact, research revealed that whenever burnout was low and staff was adequate, less infection occurred among nurses.

\section{Conclusion}

Despite the shortage of nurses at Spanish Town hospital, the researcher has never encountered practically any systematic empirical inquiry that aims to disentangle the factors that influence 'burnout' among nurses as well as the rate of 'burnout' among nurses at the Spanish Town Hospital. This research is timely as it aims to identify factors of 'burnout' among nurses at the Spanish Town Hospital and to determine the level of 'burnout' among nurses.

\section{Materials and Methods}

\section{Overview}

The present research seeks to evaluate "Factors that contribute to "burnout" among Nursing Staff at the Spanish Town Hospital, St. Catherine, Jamaica" and the level of 'burnout' among then uses" (Figures $3 \& 4$ ).

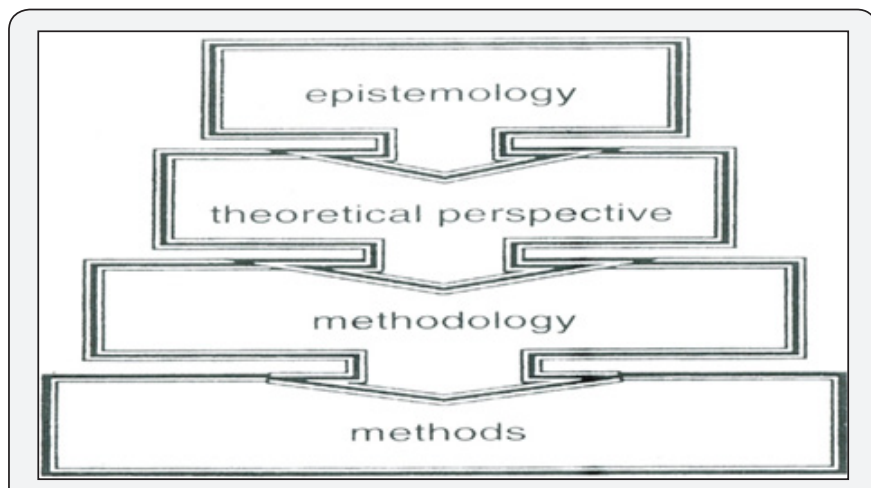

Figure 3: Linking Epistemologies, Theories, Methodologies and Methods.



Figure 4 : Four elements of objectivistic epistemology.

\section{Research Design}

This study will employ a quantitative research design that is cross-sectional in nature. It is a cross-sectional probability sample survey (i.e., stratified random sampling) of nurses at the Spanish Town Hospital in Saint Catherine, Jamaica. A standardized instrument will be used to collect the data for this research. This survey instrument will be used to provide data upon which this study answer the research questions on factors that determine burnout among nurses at the Spanish Town Hospital in St. Catherine, Jamaica. The survey instrument is a standardized questionnaire comprised of 45 questions, with none being open-ended. The instrument also had Sociodemographic, Social items including items on burnout. The dependent variable is burnout and the independent variables are the assumed factors that contribute to burnout.

\section{Population and Sampling}

The participants of the study will consist of nursing personnel who currently work at the Spanish Town Hospital. The sample frame will consist of a total of 327 nursing personnel who are employed at the above mentioned institutions for a minimum of 12 months-the sampling frame was obtained by the administrative office of the Spanish Town Hospital. Stratified random sampling will be used to select the nursing personnel from the hospital who will participate in the study. The number of persons in the population from each category can be seen in (Table 2). The sample size is 177 with a margin of error of 5 percent (as well as being verified by Survey Monkey).

Table 2: Number of persons in the Population.

\begin{tabular}{|c|c|}
\hline Categories & Number \\
\hline Registered nurses & 190 \\
\hline Midwives nurses & 21 \\
\hline Enroll nurses & 31 \\
\hline Patients care assistant & 78 \\
\hline Theater Assistants & 7 \\
\hline Total & 327 \\
\hline
\end{tabular}

\section{Inclusion and Exclusion Criteria}

The current study will comprise all nursing personnel who are employed at the time of the study. As such, non-nursing personnel including doctors, ancillary staffers, Chief Executive Officer (CEO), clerical and technical staffers, and porters were excluded from the study.

\section{Conceptualization and Operationalization}

The variables to be measured are 'burnout' among nursing staff (the dependent variable) and the factors accounting for the 'Burnout' among nursing staff (the independent variables). The instruments that will be used to measure the variables are The Maslach Burnout Inventory (MBI) which is by far the most widely used, accepted, valid, and reliable measurement tool of stress and burnout. The 22 total items are broken up into the three themes with nine items relating to emotional exhaustion, 
five to depersonalization, and eight to accomplishment. Each item is also rated on a frequency and intensity scale. The frequency scale ranges from zero (never) to six (everyday). The level of 'burnout' is determined by the summarization of all the items in Maslach Burnout Inventory. The large score indicate greater degree of 'burnout' and vice versa. Each participant will be required to complete the above mentioned instrument plus two others developed by the researcher to obtain demographic information to determine what factors may influence respondent answers, interest or opinion. The final instrument consist of twelve questions on a four-point Likert-type scale: SD: Strongly Disagree; D: Disagree; A: Agree; and SA: Strongly Agree to determine if social or occupational issues are contributing factors to 'Burnout' among nursing staff at the Spanish Town Hospital.

\section{Theoretical Framework}

Empirical model of attitude to work. Crotty [57] forwarded a justification for the use of a theoretical framework in research, epistemological thinking (or paradigm). He postulated that "the philosophical stance that lies behind our chosen methodology. We attempt to explain how it provides a context for the process and grounds its logic and criteria" Crotty. Therefore, the current study will employ three theoretical frameworks. One is for attitude to work, staff tenure and attitude, job satisfaction and job performance. The model of attitudes shows that attitude is influenced by values and beliefs and that intention to behavior precedes the actual behavior. Embedded in the model is some identifiable object. Human's behavior is in response to some act or action, and that attitude is in reference to some affective component. The affective component denotes the emotional tone which occurs in response towards the object of the attitude. Humans are social agents, meaning that their behavior is an expression of parental socialization as this is one way in which people acquire values, beliefs and attitude to the world and by extension their part therein. It follows that organization socialization is equally critical to the attitude of works as it a part of the culturalization of the individual as to acceptable (or otherwise) behavior. Hence, the aforementioned factors contribute to positive or negative attitude to life, including work (Figure 5).

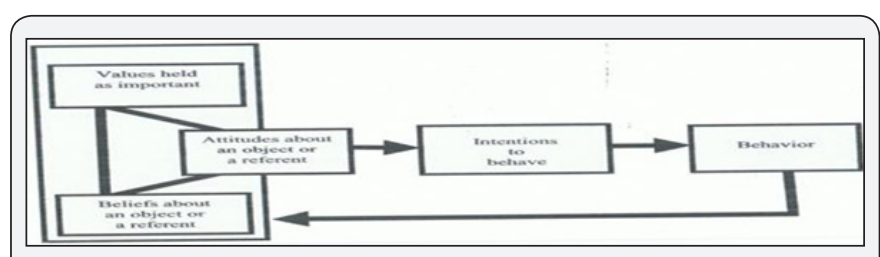

Figure 5 : A model of Attitude.

\section{Empirical model of attitude to leave a company}

The intention to leave a company has been empirically examined by Zeytinoglu, et al. [58]. They established that the attitude to leave a company is influenced by job security, job satisfaction, commitment to the job, and particular socio- demographic characteristics -gender, age, and educational attainment. Figure 1.4 captures the relationship between different independent variables and the attitude to leave the company. Empirical model of attitude, job satisfaction and job performance. Unlike the two aforementioned presented theoretical models, this one developed by Cook [59] brings together attitude, job satisfaction and job performance in a single model, while excluding retention. The relationship between attitudes and job satisfaction, and job attitude and performance is captured herein as all the tenet of attitude do not directly job satisfaction likewise job performance; but they are routed through job complexity, with the relationship between job satisfaction and job performance being a weak one $(r=0.30)$ (Figures 4 \& 5) (Table 3).

Table 3: Descriptive statistics of age of respondents.

\begin{tabular}{|c|c|c|c|}
\hline & & Statistic & Std. Error \\
\hline Mean & & 35.1869 & .65687 \\
\hline \multirow{2}{*}{$\begin{array}{c}95 \% \\
\text { Confidence } \\
\text { Interval for } \\
\text { Mean }\end{array}$} & Lower Bound & 33.8915 & \\
\hline & Upper Bound & 36.4823 & \\
\hline $\begin{array}{l}\text { 5\% Trimmed } \\
\text { Mean }\end{array}$ & & 34.7239 & \\
\hline Median & & 34.0000 & \\
\hline Variance & & 85.432 & \\
\hline Std. Deviation & & 9.24294 & \\
\hline Minimum & & 19.00 & \\
\hline Maximum & & 60.00 & \\
\hline Range & & 41.00 & \\
\hline $\begin{array}{l}\text { Inter quartile } \\
\text { Range }\end{array}$ & & 13.00 & \\
\hline Skewness & & .706 & .173 \\
\hline Kurtosis & & -.168 & .344 \\
\hline
\end{tabular}

\section{Data Collection}

The researcher will obtain approval from the Ethics Committee at the University of Technology, Jamaica. After receiving approval the researcher will provide the participants with a package containing the necessary information, which will include a letter of introduction, explanation of the study, request for participation, consent form. The nursing staff will be required to complete both Maslach Burnout Inventory, soci-demographic, social and occupation questionnaires. All participants who agree to participate in the study will be given seven days in which to complete and return the questionnaires. Participants are to drop the completed questionnaires in a secure box that will be provided. The participants will be provided with the researcher's contact numbers to facilitate inquiries about the 
survey instruments and or to make alternative arrangements for the collection of questionnaires. The researcher will seek approval from the above mentioned institutions before the survey instrument is administered. Assurance of confidentiality and anonymity will be given to all participants prior to them signing the consent form and completing the questionnaires. All participants who agree to participate in the study will be given a seven days period in which to complete same after which they will be placed in a designated box that will be place on the different units. All the boxes will be collected by the researcher at the end of the period.

\section{Validity and Reliability}

Thomas Kuhn who had a doctorate in physics argued expensively on the validity and verifiability of qualitative inquiry despite it's seemingly non-objectivism. Knowing how things operate was not singly embedded in empiricism, objective measurability and statistical analyses as meaning accounts for actions that are sometimes outside of the realm of objectivism $[60,61]$. It can be extrapolated from Kuhn's perspectives that validity and reliability is equally important in all scientific inquiry, and the issues of conceptualization and measurement must include an aspect of validity and verification. For any research project to be credible, its reliability and validity have to be clearly established Wiersman [62]. As such, the necessary steps taken to ensure that the proposed project has both internal and external validity and internal and external reliability on the instrument used are outlined. According to Wiersman, reliability is concerned with the reliability and consistency of the methods, conditions and results while validity deals with the accurate interpretability of the results and the generalizability of the results. In order to ensure a high response rate on the questionnaire, the researcher ensured that all steps were taken to have the number of items not more than is necessary to elicit the required information, thus avoiding unnecessary and ambiguous questions.

In this study, reliability of some items was based on Equivalence Reliability-Cronbach alpha Neuman. This was compared based on high or low values of Cronbach alpha. Reliability was increased by way of using: previously tested items (or questions); pre-testing, testing and post-testing of items. The researcher adheres to the following types of measuring validity: Face validity; Content validity; Criterion Validity; Concurrent validity Neuman. Several studies carried out by Iwanicki and Schwab and Gold support reliability such as the three-factor structure and internal reliability. Cronbach alpha ratings of 0.90 for emotional exhaustion, 0.76 Depersonalization, and 0.76 for Personal accomplishment were reported by Schwab; very similar ratings were reported by Gold. Time periods of a few weeks, 3 months, and 1 year were used for test-retest reliability.

Scores in the few week range were the highest (.60-.82) whereas scores in the year range were the lowest (0.54-0.60). The test manual covers validity for the MPI by noting patterns that appear again in the field. For example, male teachers score higher then female in the depersonalization scale, which is consistent with other helping professions. Before the researcher begins collecting data from the sampled participants, the other instruments will be brought through testing, retesting and modifications, which are referred to as pilot testing process. The instrument will be forwarded to my supervisor who will vet the items. The modifications will be made based on the comments of the supervisor. The instrument will then be given to measurement practitioners, statisticians, social researchers and demographers for them to vet the items. The comments of those individuals will be incorporated in the instrument and then will be tested on a similar group of nurses.

\section{Data Analysis}

For this study, data will be stored, retrieved and analyzed using the Statistical Packages for the Social Sciences (SPSS) for Windows version 20.0 (SPSS Inc; Chicago, IL, USA). Descriptive statistics, percentages and frequency distributions will be performed on the available data. Ordinary least square (OLS) regression will be employed to examine the factors that account for 'burnout' among nursing staff at the Spanish Town Hospital. Cross tabulations will be utilized to examine associations (or not) among two non-metric variables. Independent sample t-test will be employed to determine the difference between two variablesone being metric and the other being dichotomous nominal variable. Statistical significance will determined a p-value less than or equal to five percentage points $(\leq 0.05)$-two-tailed. The data will be collected by a 7-point standardized questionnaire, after which it will be entered in the Statistical Packages for the Social Sciences (SPSS) for Windows, Version 21.0, with a $p$ value of less than $5 \%$ will be used to determined statistical significance. Data will be analyzed by way of cross tabulations, analysis of variance (ANOVA), and multivariate regressions for instance ordinary least square and binary. The information will be presented using graphs and tables.

\section{Ethical Issues}

Ethical clearance will be solicited from the ethics committees of the Spanish Town Hospital. All the participants will be required to give their consent prior to being included in the study. Participant will be assured of confidentiality and anonymity unless permission is granted to do otherwise. All participants will be advised that at the end of the study all questionnaires will be destroyed. The information gathered will be used solely for the purpose of this study (Tables $4 \& 5$ ).

Table 4: Tests of Normality.

\begin{tabular}{|c|c|c|c|c|c|c|}
\hline & $\begin{array}{c}\text { Kolmogorov- } \\
\text { Smirnova }\end{array}$ & $\begin{array}{c}\text { Shapiro- } \\
\text { Wilk }\end{array}$ & & & \\
\hline & Statistic & $\mathrm{df}$ & Sig. & Statistic & $\mathrm{df}$ & Sig. \\
\hline $\begin{array}{c}\text { Age at last } \\
\text { birthday }\end{array}$ & .137 & 198 & .000 & .944 & 198 & .000 \\
\hline
\end{tabular}

aLilliefors Significance Correction. 
Table 5: Descriptive statistics of length of time in profession and length of time in current profession.

\begin{tabular}{|c|c|c|c|c|}
\hline & & & Statistic & Std. Error \\
\hline \multirow{13}{*}{$\begin{array}{l}\text { Length of time in } \\
\text { profession }\end{array}$} & Mean & & 6.4058 & 0.3625 \\
\hline & $\begin{array}{l}95 \% \text { Confidence Interval } \\
\text { for Mean }\end{array}$ & Lower Bound & 5.6907 & \\
\hline & & Upper Bound & 7.1209 & \\
\hline & 5\% Trimmed Mean & & 5.9556 & \\
\hline & Median & & 4 & \\
\hline & Variance & & 24.835 & \\
\hline & Std. Deviation & & 4.98351 & \\
\hline & Minimum & & 1 & \\
\hline & Maximum & & 24 & \\
\hline & Range & & 23 & \\
\hline & Inter quartile Range & & 6 & \\
\hline & Skewness & & 1.296 & 0.177 \\
\hline & Kurtosis & & 1.336 & 0.352 \\
\hline \multirow{13}{*}{$\begin{array}{l}\text { Length of time in current } \\
\text { profession }\end{array}$} & Mean & & 2.2751 & 0.06911 \\
\hline & $\begin{array}{l}\text { 95\% Confidence Interval } \\
\text { for Mean }\end{array}$ & Lower Bound & 2.1388 & \\
\hline & & Upper Bound & 2.4115 & \\
\hline & 5\% Trimmed Mean & & 2.2005 & \\
\hline & Median & & 2 & \\
\hline & Variance & & 0.903 & \\
\hline & Std. Deviation & & 0.95006 & \\
\hline & Minimum & & 0 & \\
\hline & Maximum & & 5 & \\
\hline & Range & & 5 & \\
\hline & Inter quartile Range & & 0.5 & \\
\hline & Skewness & & 1.266 & 0.177 \\
\hline & Kurtosis & & 1.909 & 0.352 \\
\hline
\end{tabular}

\section{Data Analysis of Findings and Interpretations}

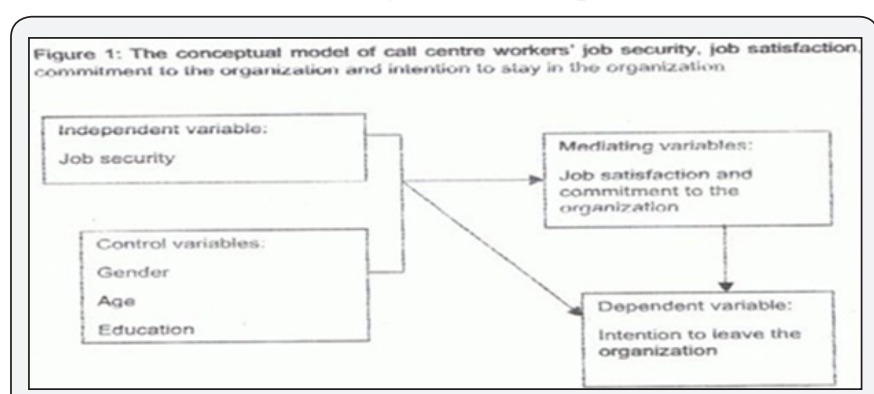

Figure 6 : Retention Model by Zeytinoglu.

Figure 1 depicts a bar graph which shows the percentage point of sample as it relates to being male or female. The sample respondents was 201 people, of which $98.5 \%(n=198)$ are females compared to $1.5 \%(n=3)$ being males. Presents descriptive statistics of the variable age at last birthday. The mean age of the respondents was 35.2years \pm 9.2 years, $95 \%$ CI: $33.9-36.5$ years. The median is 34.0 years, which indicates that there is a mild positive skewness and this is supported by the skewness value of 0.706 . The skewness value indicates that there are outliers; but that they are not problematic (or not extreme outliers or a case for concern in the data because the distribution is relatively normally distributed (Figures $6 \& 7$ ).

Depicts a histogram with a superimposed curve and this indicated that there are some positive ages that act as outliers; but that they are not extreme values to create a problem and as such the distribution is relatively normal. of the sampled respondents $(n=201)$, the response rate for this variable (marital status) was $94.5 \%(n=190)$. The majority of valid cases $(n=190)$ are single $(n=89,46.8)$ followed by married people $(n=79$, $41.6 \%)$ compared to $6.8 \%(n=13)$ who are engaged and $4.7 \%($ $\mathrm{n}=9$ ) who are divorced and/or separated from their spouse. Of the sampled respondents $(n=201), 99.5 \%(n=200)$ responded to this question (employment status) and all they indicated being permanent employees of the Spanish Town hospital (Figures 8-10). 


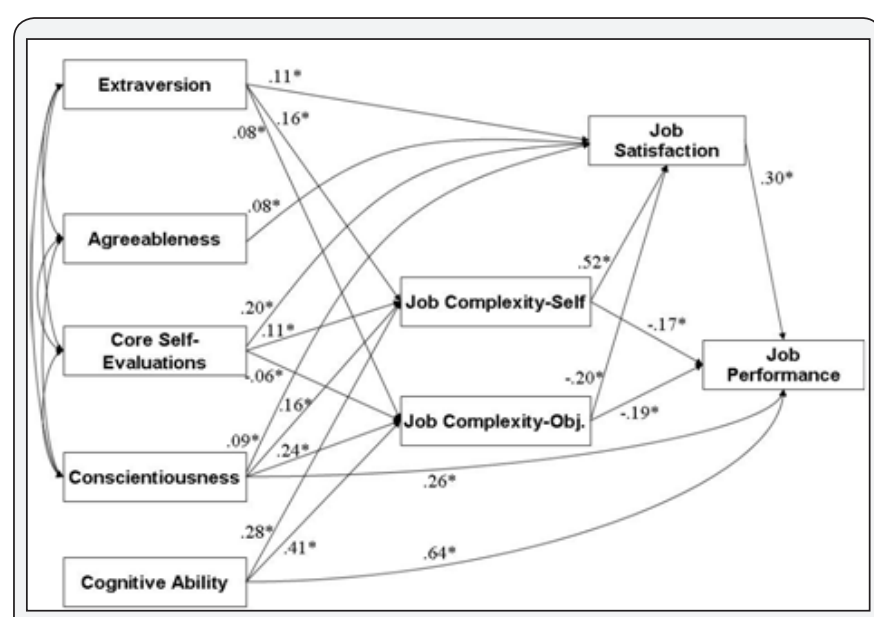

Figure 7: Integrated theoretical model of the relationships among personality, job characteristics, cognitive ability, job satisfaction, and job performance.



Figure 9 : Gender composition of sample.

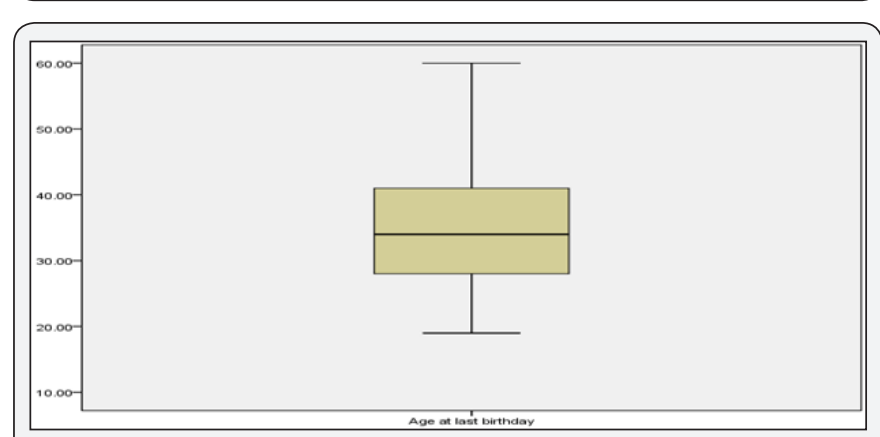

Figure 10 : Gender composition of sample.

Figure 11 shows a bar graph of the highest educational level of the sampled respondents. Of the sampled respondents $(n=201)$, $37.3 \%(n=75)$ have obtained a bachelor's degree, with $13.9 \%$ $(n=28)$ being enrolled nurses, 9.0\% $(n=18)$ were registered nurses, $1.0 \%$ having received a master's degree and $38.8 \%$ $(n=78)$ were classified as other. Figure 7 depicts a pie graph on the distribution of mode of transportation to and from work for the sampled respondents. Of the sampled respondents $(n=201)$, 99.5\% ( $\mathrm{n}=200)$ indicated a choice to this question. The majority of the respondents indicated public transport as their mode of transportation to and from work $(n=130,65.0 \%)$ compared to

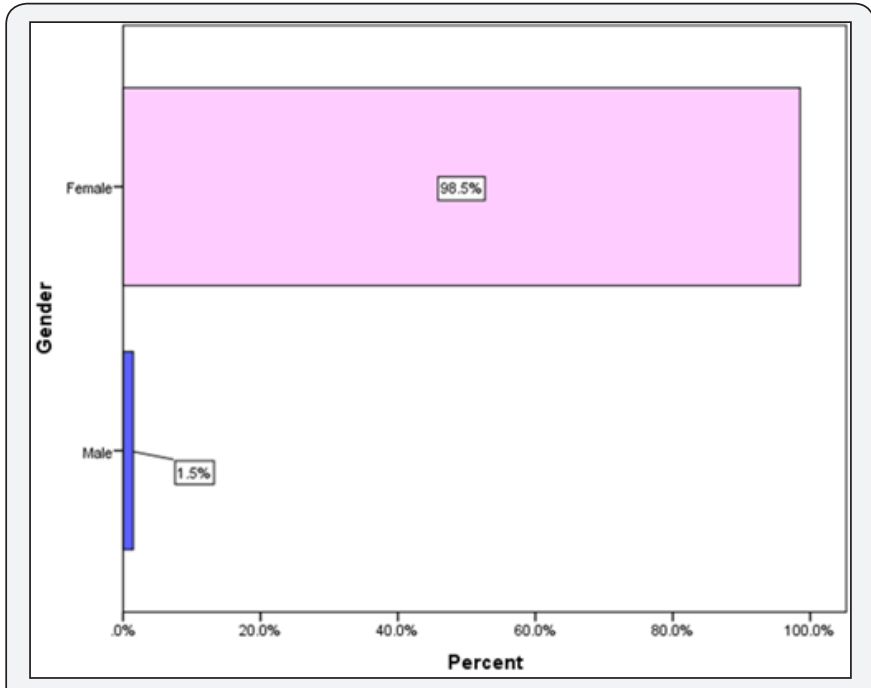

Figure 8: Gender composition of sample.

$30.0 \%(n=60)$ who reported private-mode of transport and $5.0 \%$ $(n=10)$ stated that they walk. Table 3 presents the descriptive statistics for length of time in profession and current profession. It is clear from the table that there are high skewness (sk>1.0) of each variable and that this affects the mean, which offers a rationale for the use of the median to reflect the average and not the mean that is influenced by the extreme outliers or values (Figures 12 \& 13) (Table 6).

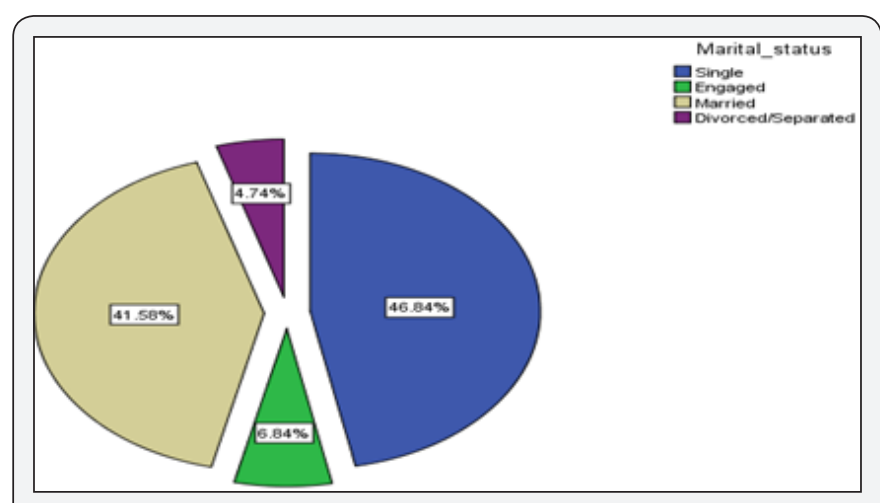

Figure 11 : Marital status composition of sample.

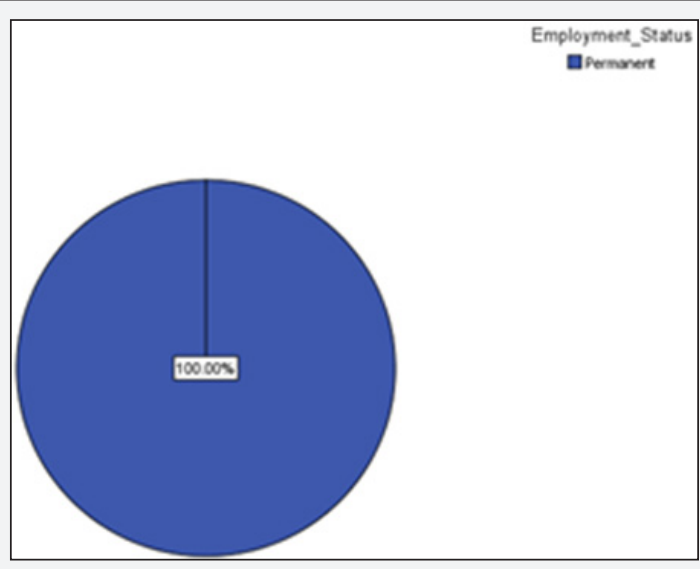

Figure 12 : Employment status. 
Table 6.

\begin{tabular}{|c|c|c|c|c|}
\hline \multirow{13}{*}{$\begin{array}{l}\text { Number of children given } \\
\text { birth to }\end{array}$} & Mean & & 1.8783 & 0.08912 \\
\hline & $\begin{array}{l}95 \% \text { Confidence Interval } \\
\text { for Mean }\end{array}$ & Lower Bound & 1.7025 & \\
\hline & & Upper Bound & 2.0541 & \\
\hline & 5\% Trimmed Mean & & 1.853 & \\
\hline & Median & & 2 & \\
\hline & Variance & & 1.501 & \\
\hline & Std. Deviation & & 1.22518 & \\
\hline & Minimum & & 0 & \\
\hline & Maximum & & 5 & \\
\hline & Range & & 5 & \\
\hline & Inter quartile Range & & 2 & \\
\hline & Skewness & & 0.217 & 0.177 \\
\hline & Kurtosis & & -0.543 & 0.352 \\
\hline \multirow{13}{*}{$\begin{array}{l}\text { How many sick days have } \\
\text { you used since this year? }\end{array}$} & Mean & & 5.4709 & 0.23956 \\
\hline & $\begin{array}{l}\text { 95\% Confidence Interval } \\
\text { for Mean }\end{array}$ & Lower Bound & 4.9983 & \\
\hline & & Upper Bound & 5.9435 & \\
\hline & 5\% Trimmed Mean & & 5.435 & \\
\hline & Median & & 6 & \\
\hline & Variance & & 10.846 & \\
\hline & Std. Deviation & & 3.29336 & \\
\hline & Minimum & & 0 & \\
\hline & Maximum & & 15 & \\
\hline & Range & & 15 & \\
\hline & Inter quartile Range & & 5 & \\
\hline & Skewness & & 0.034 & 0.177 \\
\hline & Kurtosis & & -0.665 & 0.352 \\
\hline
\end{tabular}

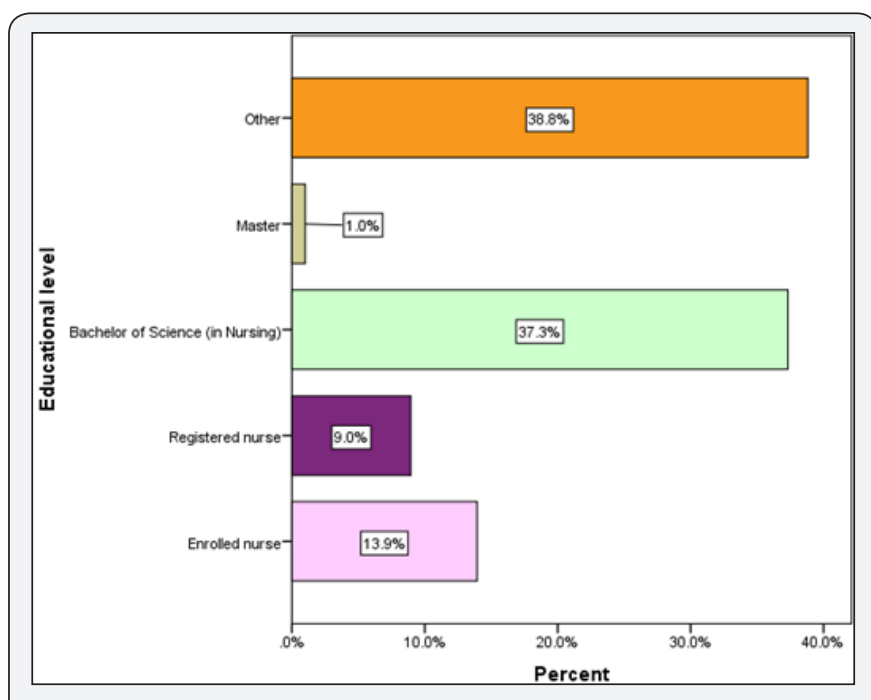

Figure 13 : Educational level of respondents.

Therefore, the average length of time spent in the profession by the sampled respondent is 4 years and 2 years in the current profession (or work). This indicates a relatively youth staff and would suggest a high turnover of nurses and nurse aides. Presents descriptive statistics of fertility and sick days used by the sampled respondents. With values for skewness being 0.217 and 0.034 , respectively, this suggests that distributions are relatively normally distributed and that data is tending towards the centre (kurtosis < 0 ). The average number of children per sampled respondents was 2 and having used 6 days for sick leave to date. (Table 7). When the respondents were asked "Do you have any of the following issues (i.e. Frequent headaches, back pain, change in appetite, abnormal weight gain or loss, gastrointestinal disturbances, muscle aches, and tiredness)? Responses are presented in Table 5, below. The majority of the sampled respondents have experienced abnormal weight gain or loss ( $n=143,71.9 \%)$ followed change in appetite $(n=135,67.8 \%)$ and gastrointestinal disturbances $(n=130,64.7 \%)$, with the least indicating 'tiredness' ( $\mathrm{n}=15,7.5 \%)$ (Table 8). The respondents were asked "On average, how many hours of sleep do you get in a night?" and descriptive statistics were done for this and this is presented in below (Figures 14-17) 


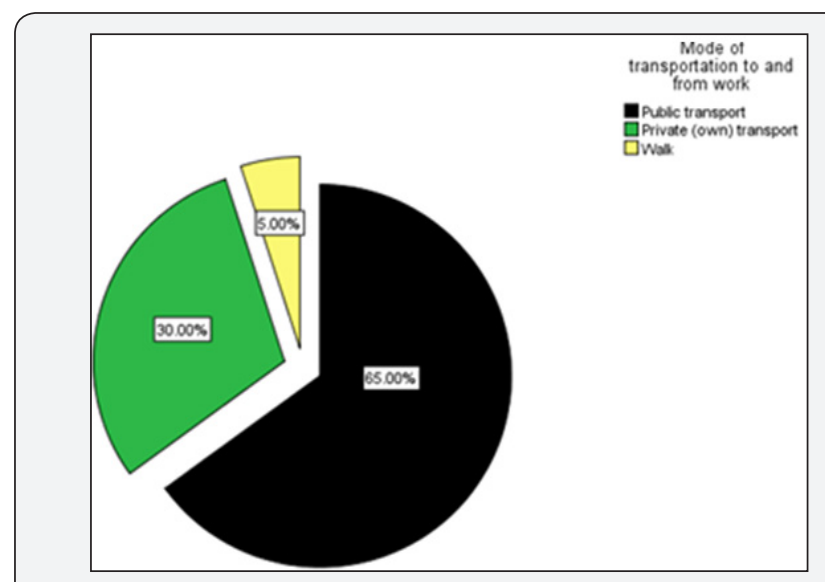

Figure 14 : Mode of transportation to and from work.

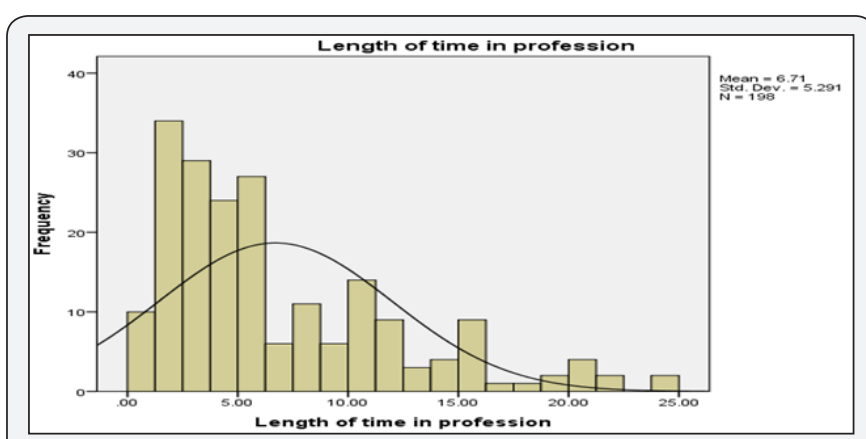

Figure 15 :Histogram and super-imposed curve of length of time in profession.

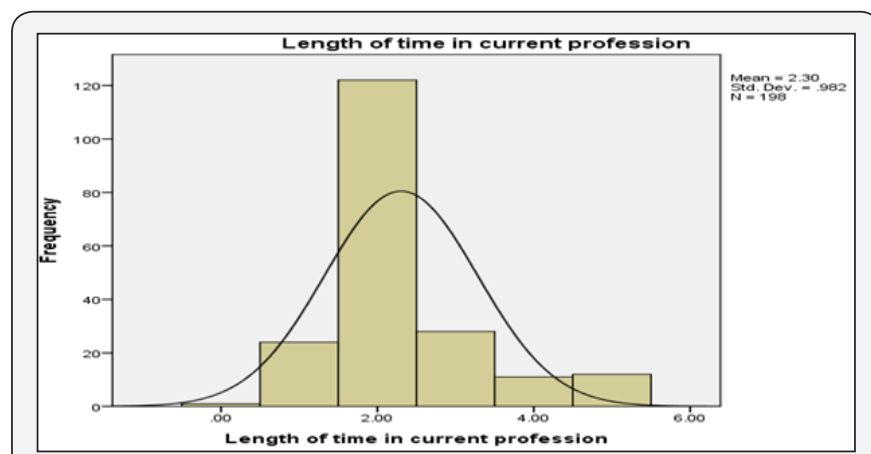

Figure 16 : Histogram and super-imposed curve of length of time in current profession.

Table 7: Experienced particular issues.

\begin{tabular}{|c|c|}
\hline Details & n (\%) \\
\hline Frequent headaches & $49(24.4)$ \\
\hline Back pain & $52(25.9)$ \\
\hline Change in appetite & $135(67.8)$ \\
\hline Abnormal weight gain or loss & $143(71.9)$ \\
\hline Gastrointestinal disturbances & $130(64.7)$ \\
\hline Muscle aches & $97(48.7)$ \\
\hline Tiredness & $15(7.5)$ \\
\hline
\end{tabular}

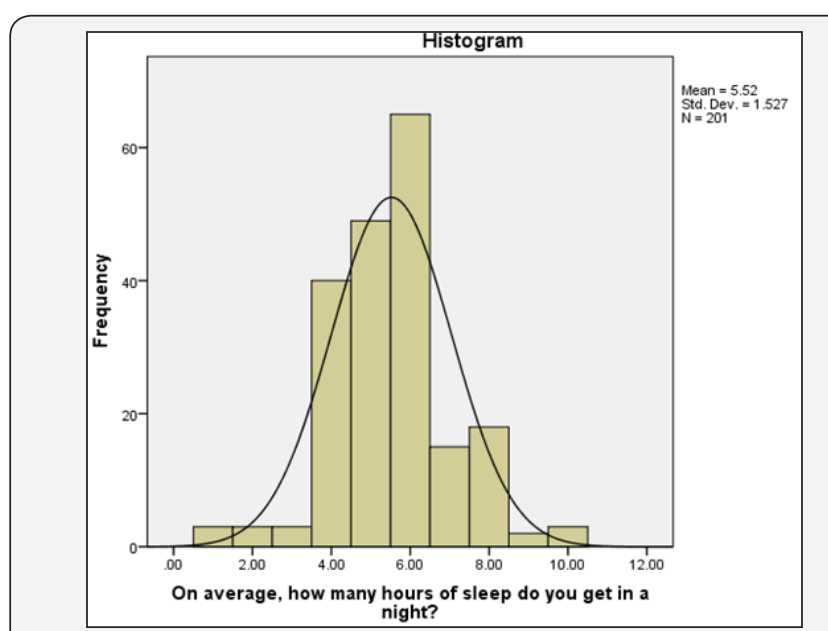

Figure 17: Bar graph and superimposed curve of number of hours a respondent sleeps each night.

Table 8: Descriptive statistics of number of hours slept each day.

\begin{tabular}{|c|c|c|c|c|}
\hline \multirow{14}{*}{$\begin{array}{l}\text { On average, } \\
\text { how many } \\
\text { hours of } \\
\text { sleep do } \\
\text { you get in a } \\
\text { night? }\end{array}$} & Mean & & Statistic & Std. Error \\
\hline & $\begin{array}{l}95 \% \\
\text { Confidence } \\
\text { Interval for } \\
\text { Mean }\end{array}$ & $\begin{array}{l}\text { Lower } \\
\text { Bound }\end{array}$ & 5.5224 & 0.10768 \\
\hline & & $\begin{array}{l}\text { Upper } \\
\text { Bound }\end{array}$ & 5.31 & \\
\hline & $\begin{array}{c}5 \% \\
\text { Trimmed } \\
\text { Mean }\end{array}$ & & 5.7347 & \\
\hline & Median & & 5.5246 & \\
\hline & Variance & & 6 & \\
\hline & $\begin{array}{c}\text { Std. } \\
\text { Deviation }\end{array}$ & & 2.331 & \\
\hline & Minimum & & 1.52668 & \\
\hline & Maximum & & 1 & \\
\hline & Range & & 10 & \\
\hline & $\begin{array}{l}\text { Inter } \\
\text { quartile } \\
\text { Range }\end{array}$ & & 9 & \\
\hline & Skewness & & 1 & \\
\hline & Kurtosis & & 0.11 & 0.172 \\
\hline & & & 1.041 & 0.341 \\
\hline
\end{tabular}

The skewness value of this variable is close to zero (ie. Sk $=0.111$ ), (Tables $9 \& 10$ ) which indicates relative normalcy of the distribution, presents descriptive statistics of items on the Maslach Burnout Inventory-1) emotional exhaustion; 2) depersonalization, and 3) accomplishment. To the question "I feel emotional drained from work", the response was at least once per week (i.e. 4.4 \pm 1.6 ) and that "I feel like I'm at the end of my rope", the average response was $2.7 \pm 1.6$, which means a few times per month. With respect to the question "I worry that this job is hardening me emotionally' the mean response was $3.7 \pm 2.1$, suggesting an occurrence of once per week, and this speaks to 


\section{Juniper Online Journal of Public Health}

this explains why on average the respondents indicated that once a month they treat patients as impersonal objects $(2.2 \pm 1.7)$. For more information on the respondents' comments on the selected items of the Maslach Burnout Inventory, this can be viewed in (Figure 18) (Tables $11 \& 12$ ).

Table 9: Tests of Normality of number of hours sleep a respondent has each night.

\begin{tabular}{|c|c|c|c|c|c|c|}
\hline & \multicolumn{2}{|c|}{ Kolmogorov-Smirnova } & \multirow[b]{2}{*}{ Sig. } & \multicolumn{2}{|c|}{ Shapiro-Wilk } & \multirow[b]{2}{*}{ Sig. } \\
\hline & Statistic & $\mathrm{df}$ & & Statistic & $\mathrm{df}$ & \\
\hline $\begin{array}{l}\text { On average, how many hours of sleep do } \\
\text { you get in a night? }\end{array}$ & .188 & 201 & .000 & .935 & 201 & .000 \\
\hline
\end{tabular}

\section{Lilliefors Significance Correction.}

Table 10: Descriptive Statistics of Maslach Burn out Inventory.

\begin{tabular}{|c|c|c|c|c|c|}
\hline & $\mathbf{N}$ & Minimum & Maximum & Mean & Std. Deviation \\
\hline \multicolumn{6}{|c|}{ Emotional Exhaustion } \\
\hline I feel emotionally drained from work & 201 & 0 & 6 & 4.4 & 1.6 \\
\hline I feel used up at the end of the workday & 201 & 0 & 6 & 4.3 & 1.4 \\
\hline $\begin{array}{l}\text { I feel fatigued when I get up in the morning and have to } \\
\text { face another day }\end{array}$ & 200 & 0 & 6 & 4.1 & 1.4 \\
\hline Working with people all day is really a strain on me & 200 & 0 & 6 & 2.7 & 1.6 \\
\hline I feel burned out from my work & 200 & 0 & 6 & 3.8 & 1.5 \\
\hline I feel frustrated by my job & 201 & 0 & 6 & 3.3 & 1.6 \\
\hline I feel I'm working too hard on my job & 200 & 0 & 6 & 3.9 & 1.7 \\
\hline Working with people directly puts too much stress on me & 201 & 0 & 6 & 2.3 & 1.4 \\
\hline I feel like I'm at the end of my rope & 200 & 0 & 6 & 2.7 & 1.6 \\
\hline \multicolumn{6}{|l|}{ Depersonalization } \\
\hline $\begin{array}{l}\text { I feel I treat some patients as if they were impersonal } \\
\text { objects }\end{array}$ & 200 & 0 & 6 & 2.2 & 1.7 \\
\hline $\begin{array}{l}\text { I've become more callous toward people since I took this } \\
\text { job }\end{array}$ & 199 & 0 & 6 & 2 & 1.7 \\
\hline I worry that this job is hardening me emotionally & 199 & 0 & 6 & 3.7 & 2.1 \\
\hline I don't really care what happens to some patients & 198 & 0 & 6 & 1.7 & 1.6 \\
\hline I feel patients blame me for some of their problems & 200 & 0 & 6 & 3.3 & 1.8 \\
\hline \multicolumn{6}{|l|}{ Accomplishment } \\
\hline I can easily understand how my patients feel about things & 198 & 1 & 6 & 3.8 & 1.3 \\
\hline I deal very effectively with the problems of my patients & 199 & 0 & 6 & 3.3 & 1.6 \\
\hline $\begin{array}{l}\text { I feel I'm positively influencing other people's lives } \\
\text { through my work }\end{array}$ & 200 & 0 & 6 & 3.2 & 1.8 \\
\hline I feel very energetic & 201 & 0 & 6 & 2.4 & 1.5 \\
\hline I can easily create a relaxed atmosphere with my patients & 201 & 0 & 6 & 3.1 & 1.5 \\
\hline I feel exhilarated after working closely with my patients. & 200 & 0 & 6 & 2.8 & 1.5 \\
\hline I have accomplished many worthwhile things in this job & 199 & 0 & 39 & 2.2 & 3.2 \\
\hline In my work, I deal with emotional problems very calmly & 199 & 0 & 6 & 3.2 & 1.4 \\
\hline
\end{tabular}


Table 11: Descriptive Statistics on subscale of Maslach Burnout Inventory.

\begin{tabular}{|c|c|c|c|c|c|}
\hline & $\mathbf{N}$ & Minimum & Maximum & Mean & Std. Deviation \\
\hline Emotional Exhaustion & 201 & 6 & 52 & 31.4 & 9 \\
\hline Depersonalization & 201 & 0 & 24 & 12.8 & 5.2 \\
\hline Accomplishment & 201 & 3 & 59 & 23.8 & 7.8 \\
\hline \multirow[t]{2}{*}{ Overall score } & 201 & 15 & 119 & 68.1 & 12.8 \\
\hline & $\begin{array}{l}\text { Emotional } \\
\text { Exhaustion }\end{array}$ & Depersonalization & $\begin{array}{c}\text { Personal } \\
\text { Accomplishment }\end{array}$ & & \\
\hline aLow & $\leq 20(13.30 \%)$ & $\leq 5(28.90 \%)$ & $\geq 42(76.70 \%)$ & aLow & $\leq 20(13.30 \%)$ \\
\hline Moderate & $21-30(26.10 \%)$ & $6-10(31.10 \%)$ & $41-36(21.70 \%)$ & Moderate & $21-30(26.10 \%)$ \\
\hline High & $\geq 31(60.60 \%)$ & $\geq 11(40.00 \%)$ & $\leq 35(1.70 \%)$ & High & $\geq 31(60.60 \%)$ \\
\hline
\end{tabular}

Table 12: Reliability Statistics.

\begin{tabular}{|c|c|c|}
\hline Cronbach's Alpha & $\begin{array}{c}\text { Cronbach's } \\
\text { Alpha Based on } \\
\text { Standardized Items }\end{array}$ & N of Items \\
\hline .623 & .654 & 22 \\
\hline
\end{tabular}

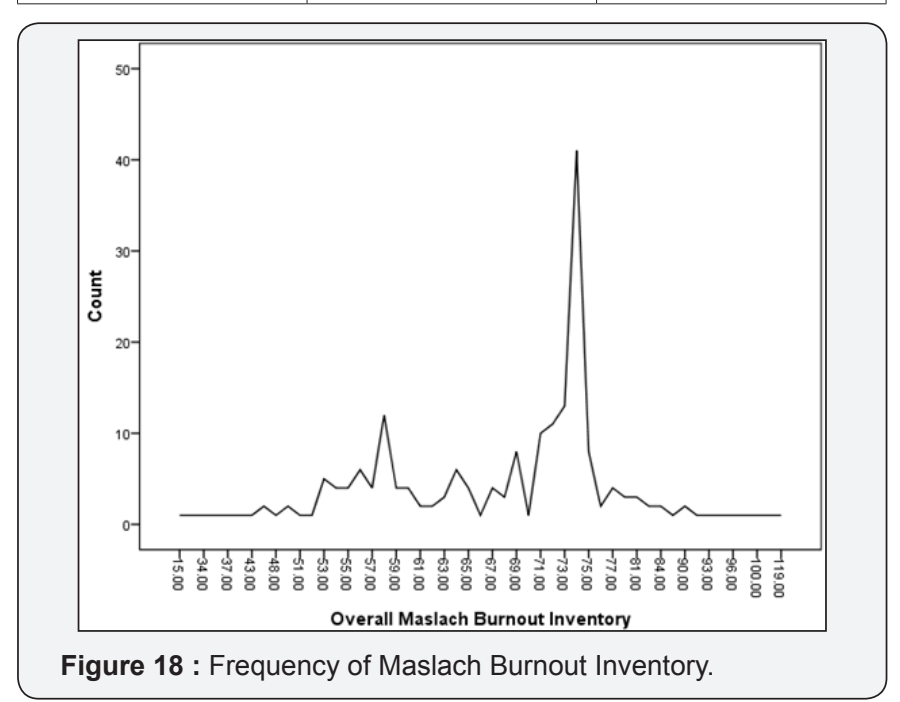

Presents the overall descriptive statistics for Maslach Burnout Inventory as well as the subscales of the index. Generally, Maslach Burnout Inventory for the sampled respondents had a mean score of $68.1 \pm 12.8$. It can be deduced from the mean score for the overall Inventory that burnout among the sampled respondents is very high, with personal fulfillment being high as well as emotional exhaustion (Table 13). Burnout among the sampled respondents is not a constant phenomenon, and this should be noted that the issue has peaks and troughs. The highest peak on the Maslach Burnout Inventory indicates many nursing professionals are burnout at this point. A number of social and occupational indicators were examined and the responses are presented in below. Table 11 presents descriptive statistics on items that constitute the various social indicators. Various statements were made to the respondents and they were to provide a response to each. To the statement "I receive social support from my colleagues", and the mean score was $1.7 \pm 0.9$, suggesting that this was rarely done (i.e., once a month), which was also the case for "I receive social support from my managers", and "As a team working together we attend team building sessions." Other issues are presented in below (Figures 19-21) (Table 14).

Table 13: Item-Total Statistics.

\begin{tabular}{|c|c|c|c|c|c|}
\hline & $\begin{array}{c}\text { Scale Mean if Item } \\
\text { Deleted }\end{array}$ & $\begin{array}{c}\text { Scale Variance if } \\
\text { Item Deleted }\end{array}$ & $\begin{array}{c}\text { Corrected Item-Total } \\
\text { Correlation }\end{array}$ & $\begin{array}{c}\text { Squared Multiple } \\
\text { Correlation }\end{array}$ & $\begin{array}{c}\text { Cronbach's Alpha if } \\
\text { Item Deleted }\end{array}$ \\
\hline ques1 & 64.1803 & 132.27 & 0.427 & 0.665 & 0.585 \\
\hline ques2 & 64.2842 & 136.227 & 0.399 & 0.683 & 0.593 \\
\hline ques3 & 64.3934 & 137.581 & 0.386 & 0.714 & 0.595 \\
\hline ques4 & 64.8251 & 143.552 & 0.2 & 0.581 & 0.613 \\
\hline ques5 & 66.2131 & 138.806 & 0.241 & 0.682 & 0.608 \\
\hline ques6 & 65.8033 & 128.873 & 0.565 & 0.654 & 0.57 \\
\hline ques7 & 65.224 & 150.373 & -0.04 & 0.58 & 0.638 \\
\hline ques8 & 64.7432 & 136.478 & 0.377 & 0.494 & 0.594 \\
\hline ques9 & 65.3279 & 156.123 & -0.183 & 0.53 & 0.657 \\
\hline ques10 & 66.5301 & 145.635 & 0.073 & 0.435 & 0.627 \\
\hline ques11 & 64.8142 & 131.251 & 0.333 & 0.655 & 0.594 \\
\hline ques12 & 66.0546 & 148.426 & 0.021 & 0.496 & 0.631 \\
\hline ques13 & 65.2678 & 125.67 & 0.644 & 0.706 & 0.559 \\
\hline
\end{tabular}


Juniper Online Journal of Public Health

\begin{tabular}{|c|c|c|c|c|c|}
\hline ques14 & 64.6503 & 139.745 & 0.228 & 0.451 & 0.609 \\
\hline ques15 & 66.7541 & 144.989 & 0.102 & 0.549 & 0.624 \\
\hline ques16 & 66.2295 & 140.376 & 0.292 & 0.482 & 0.604 \\
\hline ques17 & 65.4973 & 150.185 & -0.03 & 0.416 & 0.636 \\
\hline ques18 & 65.7814 & 151.446 & -0.067 & 0.397 & 0.641 \\
\hline ques19 & 66.4153 & 138.266 & 0.029 & 0.344 & 0.666 \\
\hline ques20 & 65.7978 & 135.338 & 0.38 & 0.496 & 0.593 \\
\hline ques21 & 65.3825 & 143.886 & 0.174 & 0.465 & 0.616 \\
\hline ques22 & 65.1913 & 130.364 & 0.447 & 0.58 & 0.581 \\
\hline
\end{tabular}



Figure 19 : Annex 1.

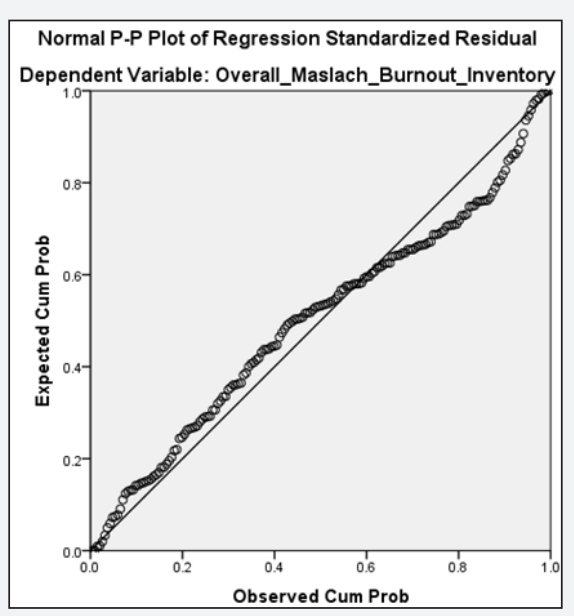

Figure 20

Table 14: Descriptive statistics of social indicators.

\begin{tabular}{|c|c|c|c|c|c|}
\hline & $\mathbf{N}$ & Minimum & Maximum & Mean & Std. Deviation \\
\hline \multicolumn{6}{|c|}{ SOCIAL FACTORS } \\
\hline I receive social support from my colleagues & 201 & 1.00 & 4.00 & 1.7 & .94892 \\
\hline I receive social support from my managers & 201 & 1.00 & 4.00 & 1.8 & 0.8 \\
\hline As a team working together we attend team building sessions & 200 & 1.00 & 4.00 & 1.7 & 0.8 \\
\hline \multicolumn{6}{|c|}{ Occupational factors } \\
\hline I attended a time management workshop & 200 & 1.00 & 4.00 & 1.5 & 0.7 \\
\hline Stress management is offered at the hospital & 199 & 1.00 & 4.00 & 1.7 & 0.7 \\
\hline $\begin{array}{l}\text { I attend in-service training and workshops to update my knowledge } \\
\text { and skills }\end{array}$ & 200 & 1.00 & 4.00 & 1.8 & 0.9 \\
\hline I have coping strategies to cope with my stress at work & 200 & 1.00 & 4.00 & 2.1 & 0.9 \\
\hline I feel there is poor communication amongst staff in the unit & 198 & 1.00 & 4.00 & 2.8 & 0.7 \\
\hline I get recognized for the work I do & 199 & 1.00 & 4.00 & 1.5 & 0.8 \\
\hline I have a clear job descriptive (role clarity) & 199 & 1.00 & 4.00 & 2.7 & 0.7 \\
\hline $\begin{array}{l}\text { I feel uncertain about what should be accomplished in my jo (role } \\
\text { ambiguity) }\end{array}$ & 199 & 1.00 & 4.00 & 2.4 & 0.7 \\
\hline
\end{tabular}




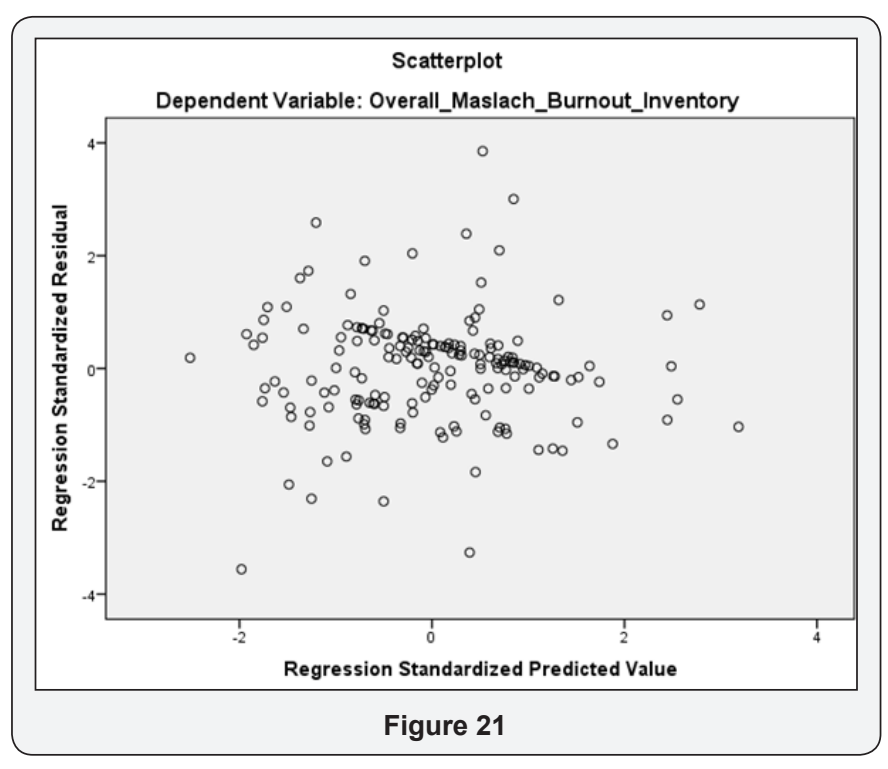

Table 11 presents a Pearson's Product Moment Correlations matrix of Maslach Burnout Inventory, social and occupation variables, and selected demographic characteristics. Of all the variables examined in the Pearson's Product Moment Correlations matrix, 7 emerged as having a statistical bivariate relationship with Maslach Burnout Inventory. Direct correlations were found to be with 1$)$ age $(r=0.144, P=0.027)$, length of time in profession $(\mathrm{r}=0.172, \mathrm{P}=0.011)$, and length of time in current post $(\mathrm{r}=0.170, \mathrm{P}=0.012)$-Table 11 . This denotes that the older nursing professionals become the more likely they will be burnout which is supported by time in the profession as well as in their present job. It can be deduced from the findings that nursing is highly demand profession and is highly likely to result in burnout with more time in the area. On the other hand, social factor $(r=-0.138, P=0.033)$, number of sick days taken $(r=-0.177, P=0.012)$, and average number of hours slept $(\mathrm{r}=-0.240, \mathrm{P}=0.001)$ are inversely correlated with burnout among the sampled respondents. Such a finding denotes that the nursing professionals who take more sick days were less likely to be burnout and this highlights a fact that some of the nursing professionals are burnout on the job (Tables 15-20).

Table 15: Pearson's Product Moment Correlations of Maslach Burnout Inventory and selected demographic and other variables.

\begin{tabular}{|c|c|c|c|c|c|c|c|c|c|c|c|}
\hline & & $\begin{array}{c}\text { Overall } \\
\text { Maslach } \\
\text { Burnout } \\
\text { Inventory }\end{array}$ & $\begin{array}{l}\text { Social } \\
\text { Factors }\end{array}$ & $\begin{array}{l}\text { Occupa- } \\
\text { tional } \\
\text { Factors }\end{array}$ & $\begin{array}{l}\text { Age at last } \\
\text { birthday }\end{array}$ & $\begin{array}{l}\text { Length of } \\
\text { time in } \\
\text { profession }\end{array}$ & $\begin{array}{l}\text { Length of } \\
\text { time in } \\
\text { current } \\
\text { profession }\end{array}$ & $\begin{array}{l}\text { Number } \\
\text { of } \\
\text { children } \\
\text { given } \\
\text { birth to }\end{array}$ & $\begin{array}{c}\text { On } \\
\text { average, } \\
\text { how } \\
\text { many } \\
\text { hours of } \\
\text { sleep do } \\
\text { you get } \\
\text { in a } \\
\text { night? }\end{array}$ & Single & Engaged \\
\hline \multirow{12}{*}{$\begin{array}{l}\text { Pearson } \\
\text { Correl- } \\
\text { ation }\end{array}$} & $\begin{array}{l}\text { Over all Maslach } \\
\text { Burnout Inventory }\end{array}$ & 1 & -0.138 & -0.097 & 0.144 & 0.172 & 0.17 & 0.004 & -0.24 & 0.001 & 0.065 \\
\hline & $\begin{array}{l}\text { Social } \\
\text { Factors }\end{array}$ & -0.138 & 1 & 0.643 & -0.115 & -0.131 & -0.026 & -0.141 & 0.009 & 0.128 & -0.039 \\
\hline & $\begin{array}{l}\text { Occupational } \\
\text { Factors }\end{array}$ & -0.097 & 0.643 & 1 & -0.093 & -0.035 & 0.019 & -0.099 & -0.007 & 0.108 & -0.082 \\
\hline & Age at last birthday & 0.144 & -0.115 & -0.093 & 1 & 0.742 & 0.578 & 0.562 & -0.074 & -0.331 & -0.072 \\
\hline & $\begin{array}{l}\text { Length of time in } \\
\text { profession }\end{array}$ & 0.172 & -0.131 & -0.035 & 0.742 & 1 & 0.756 & 0.568 & -0.087 & -0.313 & -0.176 \\
\hline & $\begin{array}{l}\text { Length of time in } \\
\text { current profession }\end{array}$ & 0.17 & -0.026 & 0.019 & 0.578 & 0.756 & 1 & 0.41 & -0.027 & -0.28 & -0.151 \\
\hline & $\begin{array}{l}\text { Number of children } \\
\text { given birth to }\end{array}$ & 0.004 & -0.141 & -0.099 & 0.562 & 0.568 & 0.41 & 1 & 0.022 & -0.27 & -0.034 \\
\hline & $\begin{array}{l}\text { On average, how } \\
\text { many hours of } \\
\text { sleep do you get in } \\
\text { a night? }\end{array}$ & -0.24 & 0.009 & -0.007 & -0.074 & -0.087 & -0.027 & 0.022 & 1 & -0.106 & -0.02 \\
\hline & Single & 0.001 & 0.128 & 0.108 & -0.331 & -0.313 & -0.28 & -0.27 & -0.106 & 1 & -0.255 \\
\hline & Engaged & 0.065 & -0.039 & -0.082 & -0.072 & -0.176 & -0.151 & -0.034 & -0.02 & -0.255 & 1 \\
\hline & Married & -0.09 & -0.077 & -0.012 & 0.249 & 0.265 & 0.259 & 0.247 & 0.111 & -0.798 & -0.225 \\
\hline & Public Transport & -0.001 & -0.108 & -0.042 & 0.005 & -0.052 & 0.016 & -0.065 & -0.061 & 0.057 & 0.054 \\
\hline & $\begin{array}{l}\text { Over all Maslach } \\
\text { Burnout Inventory }\end{array}$ & . & 0.033 & 0.099 & 0.027 & 0.011 & 0.012 & 0.478 & 0.001 & 0.494 & 0.195 \\
\hline & $\begin{array}{l}\text { Social } \\
\text { Factors }\end{array}$ & 0.033 & . & 0 & 0.063 & 0.04 & 0.366 & 0.03 & 0.453 & 0.043 & 0.302 \\
\hline
\end{tabular}


Juniper Online Journal of Public Health

\begin{tabular}{|c|c|c|c|c|c|c|c|c|c|c|c|}
\hline & $\begin{array}{l}\text { Occupational } \\
\text { Factors }\end{array}$ & 0.099 & 0 & . & 0.107 & 0.319 & 0.401 & 0.093 & 0.46 & 0.075 & 0.137 \\
\hline & Age at last birthday & 0.027 & 0.063 & 0.107 & . & 0 & 0 & 0 & 0.162 & 0 & 0.17 \\
\hline & $\begin{array}{l}\text { Length of time in } \\
\text { profession }\end{array}$ & 0.011 & 0.04 & 0.319 & 0 & . & 0 & 0 & 0.124 & 0 & 0.009 \\
\hline & $\begin{array}{l}\text { Length of time in } \\
\text { current profession }\end{array}$ & 0.012 & 0.366 & 0.401 & 0 & 0 & . & 0 & 0.358 & 0 & 0.022 \\
\hline & $\begin{array}{l}\text { Number of children } \\
\text { given birth to }\end{array}$ & 0.478 & 0.03 & 0.093 & 0 & 0 & 0 & . & 0.387 & 0 & 0.328 \\
\hline & $\begin{array}{l}\text { On average, how } \\
\text { many hours of } \\
\text { sleep do you get in } \\
\text { a night? }\end{array}$ & 0.001 & 0.453 & 0.46 & 0.162 & 0.124 & 0.358 & 0.387 & . & 0.079 & 0.394 \\
\hline & Single & 0.494 & 0.043 & 0.075 & 0 & 0 & 0 & 0 & 0.079 & . & 0 \\
\hline & Engaged & 0.195 & 0.302 & 0.137 & 0.17 & 0.009 & 0.022 & 0.328 & 0.394 & 0 & . \\
\hline & Married & 0.115 & 0.152 & 0.438 & 0 & 0 & 0 & 0 & 0.069 & 0 & 0.001 \\
\hline & Public Transport & 0.494 & 0.075 & 0.29 & 0.474 & 0.246 & 0.413 & 0.193 & 0.21 & 0.223 & 0.235 \\
\hline & $\begin{array}{c}\text { Number of sick } \\
\text { leave }\end{array}$ & 0.012 & 0.095 & 0.02 & 0.438 & 0.25 & 0.139 & 0.029 & 0.008 & 0.229 & 0.144 \\
\hline \multirow{13}{*}{$\begin{array}{c}\text { Sig. } \\
\text { (1-tailed) }\end{array}$} & $\begin{array}{l}\text { Over all Maslach } \\
\text { Burnout Inventory }\end{array}$ & 174 & 174 & 174 & 174 & 174 & 174 & 174 & 174 & 174 & 174 \\
\hline & Social Factors & 174 & 174 & 174 & 174 & 174 & 174 & 174 & 174 & 174 & 174 \\
\hline & $\begin{array}{l}\text { Occupational } \\
\text { Factors }\end{array}$ & 174 & 174 & 174 & 174 & 174 & 174 & 174 & 174 & 174 & 174 \\
\hline & Age at last birthday & 174 & 174 & 174 & 174 & 174 & 174 & 174 & 174 & 174 & 174 \\
\hline & $\begin{array}{l}\text { Length of time in } \\
\text { profession }\end{array}$ & 174 & 174 & 174 & 174 & 174 & 174 & 174 & 174 & 174 & 174 \\
\hline & $\begin{array}{l}\text { Length of time in } \\
\text { current profession }\end{array}$ & 174 & 174 & 174 & 174 & 174 & 174 & 174 & 174 & 174 & 174 \\
\hline & $\begin{array}{l}\text { Number of children } \\
\text { given birth to }\end{array}$ & 174 & 174 & 174 & 174 & 174 & 174 & 174 & 174 & 174 & 174 \\
\hline & $\begin{array}{l}\text { On average, how } \\
\text { many hours of } \\
\text { sleep do you get in } \\
\text { a night? }\end{array}$ & 174 & 174 & 174 & 174 & 174 & 174 & 174 & 174 & 174 & 174 \\
\hline & Single & 174 & 174 & 174 & 174 & 174 & 174 & 174 & 174 & 174 & 174 \\
\hline & Engaged & 174 & 174 & 174 & 174 & 174 & 174 & 174 & 174 & 174 & 174 \\
\hline & Married & 174 & 174 & 174 & 174 & 174 & 174 & 174 & 174 & 174 & 174 \\
\hline & Public Transport & 174 & 174 & 174 & 174 & 174 & 174 & 174 & 174 & 174 & 174 \\
\hline & $\begin{array}{c}\text { Number of sick } \\
\text { leave }\end{array}$ & 174 & 174 & 174 & 174 & 174 & 174 & 174 & 174 & 174 & 174 \\
\hline
\end{tabular}

Table 16: Model Summary.

\begin{tabular}{|c|c|c|c|c|c|c|c|}
\hline Model & R & R Square & $\begin{array}{c}\text { Adjusted R } \\
\text { Square }\end{array}$ & $\begin{array}{c}\text { Std. Error of } \\
\text { the Estimate }\end{array}$ & $\begin{array}{c}\text { Change } \\
\text { Statistics }\end{array}$ & R Square \\
\hline & & & & & F Change & df1 \\
\hline 1 & $.410^{\mathrm{a}}$ & .168 & .106 & 12.21240 & .168 & 2.705 \\
\hline
\end{tabular}

Table 17: Anova.

\begin{tabular}{|c|c|c|c|c|c|}
\hline Model & & Sum of Squares & df & Mean Square & F \\
\hline 1 & Regression & 4840.379 & 12 & 403.365 & 2.705 \\
\hline & Residual & 24011.994 & 161 & 149.143 & $.002 \mathrm{~b}$ \\
\hline
\end{tabular}


Table 18: Coefficients.

\begin{tabular}{|c|c|c|c|c|c|c|c|c|c|c|}
\hline & $\begin{array}{l}\text { Unstandardized } \\
\text { Coefficients }\end{array}$ & & & & $\begin{array}{c}95.0 \% \\
\text { Confidence } \\
\text { Interval } \\
\text { for B }\end{array}$ & & & & Correlations & \\
\hline Model & B & Std. Error & Beta & $\mathrm{t}$ & Sig. & Lower & Upper & Zero-order & Partial & Part \\
\hline Constant & 87.087 & 9.565 & & 9.105 & 0 & 68.199 & 105.975 & & & \\
\hline Social Factors & -0.929 & 0.586 & -0.153 & -1.585 & 0.115 & -2.086 & 0.228 & -0.153 & -0.124 & -0.114 \\
\hline $\begin{array}{l}\text { Occupational } \\
\text { Factors }\end{array}$ & -0.1 & 0.364 & -0.027 & -0.275 & 0.784 & -0.819 & 0.619 & -0.107 & -0.022 & -0.02 \\
\hline $\begin{array}{l}\text { Age at last } \\
\text { birthday }\end{array}$ & 0.085 & 0.161 & 0.059 & 0.53 & 0.597 & -0.233 & 0.403 & 0.142 & 0.042 & 0.038 \\
\hline $\begin{array}{l}\text { Length of time in } \\
\text { profession }\end{array}$ & 0.106 & 0.368 & 0.041 & 0.288 & 0.773 & -0.621 & 0.833 & 0.17 & 0.023 & \\
\hline $\begin{array}{l}\text { Length of time in } \\
\text { current profession }\end{array}$ & 1.93 & 1.496 & 0.142 & 1.29 & 0.199 & -1.024 & 4.885 & 0.166 & 0.101 & \\
\hline $\begin{array}{l}\text { Number of } \\
\text { children given } \\
\text { birth to }\end{array}$ & -0.92 & 0.969 & -0.088 & -0.949 & 0.344 & -2.832 & 0.993 & 0.004 & -0.075 & \\
\hline $\begin{array}{l}\text { On average, how } \\
\text { many hours of } \\
\text { sleep do you get in } \\
\text { a night? }\end{array}$ & -1.99 & 0.669 & -0.223 & -2.974 & 0.003 & -3.311 & -0.669 & -0.266 & -0.228 & \\
\hline Single & -3.261 & 5.11 & -0.126 & -0.638 & 0.524 & -13.352 & 6.831 & -0.003 & -0.05 & \\
\hline Engaged & 1.058 & 6.17 & 0.021 & 0.172 & 0.864 & -11.125 & 13.242 & 0.07 & 0.014 & \\
\hline Married & -5.527 & 4.867 & -0.211 & -1.136 & 0.258 & -15.138 & 4.084 & -0.093 & -0.089 & \\
\hline Public Transport & -1.554 & 1.994 & -0.057 & -0.779 & 0.437 & -5.492 & 2.383 & -0.012 & -0.061 & \\
\hline $\begin{array}{c}\text { How many sick } \\
\text { days have you } \\
\text { used since this } \\
\text { year? }\end{array}$ & -0.501 & 0.301 & -0.126 & -1.662 & 0.098 & -1.096 & 0.094 & -0.171 & -0.13 & \\
\hline
\end{tabular}

Dependent Variable: Over all Maslach Burnout Inventory.

Table 19: Reliability Statistics.

\begin{tabular}{|c|c|}
\hline \multicolumn{2}{|c|}{ Cronbach's } \\
\hline Alpha & N of Items \\
\hline .801 & 11 \\
\hline
\end{tabular}

Table 20: Item-Total Statistics.

\begin{tabular}{|c|c|c|c|c|c|}
\hline & $\begin{array}{c}\text { Scale Mean if Item } \\
\text { Deleted }\end{array}$ & $\begin{array}{c}\text { Scale Variance if Item } \\
\text { Deleted }\end{array}$ & $\begin{array}{l}\text { Corrected Item-Total } \\
\text { Correlation }\end{array}$ & $\begin{array}{l}\text { Squared Multiple } \\
\text { Correlation }\end{array}$ & $\begin{array}{l}\text { Cronbach's Alpha if } \\
\text { Item Deleted }\end{array}$ \\
\hline ques35 & 19.9016 & 18.850 & .664 & .689 & .761 \\
\hline ques36 & 19.7927 & 20.123 & .584 & .566 & .772 \\
\hline ques37 & 19.8860 & 20.581 & .573 & .447 & .774 \\
\hline ques38 & 20.1244 & 20.599 & .611 & .552 & .771 \\
\hline ques39 & 19.8342 & 21.879 & .451 & .405 & .787 \\
\hline ques 40 & 19.7513 & 19.698 & .598 & .481 & .770 \\
\hline ques41 & 19.5337 & 19.938 & .592 & .449 & .771 \\
\hline
\end{tabular}


Juniper Online Journal of Public Health

\begin{tabular}{|c|c|c|c|c|c|}
\hline ques42 & 18.8031 & 24.982 & -.032 & .102 & .827 \\
\hline ques43 & 20.0415 & 20.092 & .634 & .201 & .767 \\
\hline ques44 & 18.9275 & 22.578 & .308 & .174 & .800 \\
\hline ques45 & 19.1554 & 24.455 & .034 & .824 \\
\hline
\end{tabular}

\section{Discussion}

The issue of the poor state of Jamaica's health-care system has continued to undergo tremendous pressure because of

a) The turnover of health care professionals. b) Under staffing of health-care professionals in public health care facilities.

c) Lack of available equipment in the public health-care system Carmen and Bench, Haye and Alexis, Jamaica Gleaner, WHO.

Table 21: Descriptive Statistics.

\begin{tabular}{|c|c|c|c|c|c|}
\hline & N & Minimum & Maximum & Mean & Std. Deviation \\
\hline Emotional Exhaustion & 201 & 6.00 & 52.00 & 31.4428 & 9.00155 \\
\hline Depersonalization & 201 & .00 & 24.00 & 23.8209 & 7.16760 \\
\hline Accomplishment & 201 & 3.00 & 59.00 & & 7986 \\
\hline Valid N (list wise) & 201 & & & & \\
\hline
\end{tabular}

Table 22: Descriptive.

\begin{tabular}{|c|c|c|c|c|}
\hline & & & Statistic & Std. Error \\
\hline \multirow{13}{*}{ Emotional Exhaustion } & Mean & & 31.4428 & 0.63492 \\
\hline & $\begin{array}{l}\text { 95\% Confidence Interval } \\
\text { for Mean }\end{array}$ & Lower Bound & 30.1908 & \\
\hline & & Upper Bound & 32.6948 & \\
\hline & 5\% Trimmed Mean & & 31.8751 & \\
\hline & Median & & 32 & \\
\hline & Variance & & 81.028 & \\
\hline & Std. Deviation & & 9.00155 & \\
\hline & Minimum & & 6 & \\
\hline & Maximum & & 52 & \\
\hline & Range & & 46 & \\
\hline & Inter quartile Range & & 11 & \\
\hline & Skewness & & -0.688 & 0.172 \\
\hline & Kurtosis & & 0.255 & 0.341 \\
\hline
\end{tabular}


Juniper Online Journal of Public Health

\begin{tabular}{|c|c|c|c|c|}
\hline \multirow{13}{*}{ Depersonalization } & Mean & & 12.8109 & 0.36449 \\
\hline & $\begin{array}{l}\text { 95\% Confidence Interval } \\
\text { for Mean }\end{array}$ & Lower Bound & 12.0922 & \\
\hline & & Upper Bound & 13.5297 & \\
\hline & 5\% Trimmed Mean & & 13.0232 & \\
\hline & Median & & 15 & \\
\hline & Variance & & 26.704 & \\
\hline & Std. Deviation & & 5.1676 & \\
\hline & Minimum & & 0 & \\
\hline & Maximum & & 24 & \\
\hline & Range & & 24 & \\
\hline & Inter quartile Range & & 7 & \\
\hline & Skewness & & -0.778 & 0.172 \\
\hline & Kurtosis & & -0.204 & 0.341 \\
\hline \multirow{13}{*}{ Accomplishment } & Mean & & 23.8209 & 0.55016 \\
\hline & $\begin{array}{l}\text { 95\% Confidence Interval } \\
\text { for Mean }\end{array}$ & Lower Bound & 22.736 & \\
\hline & & Upper Bound & 24.9058 & \\
\hline & 5\% Trimmed Mean & & 23.3292 & \\
\hline & Median & & 21 & \\
\hline & Variance & & 60.838 & \\
\hline & Std. Deviation & & 7.79986 & \\
\hline & Minimum & & 3 & \\
\hline & Maximum & & 59 & \\
\hline & Range & & 56 & \\
\hline & Inter quartile Range & & 8.5 & \\
\hline & Skewness & & 1.067 & 0.172 \\
\hline & Kurtosis & & 1.726 & 0.341 \\
\hline
\end{tabular}

Table 23: Maslach Burnout Inventory for current and work.

\begin{tabular}{|c|c|c|c|c|}
\hline & \multicolumn{2}{|c|}{ Current } & \multicolumn{2}{c|}{ Lahana et al. } \\
\hline & N & Mean & N & Mean \\
\hline Emotional Exhaustion & 201 & 31.4 & 180 & 31.36 \\
\hline Depersonalization & 201 & 12.8 & 180 & 11.27 \\
\hline Accomplishment & 201 & 23.8 & 180 & 44.02 \\
\hline
\end{tabular}

They found that the health-care system was identified as the 8th leading national problem faced by Jamaicans, suggesting that health-care system continues to languish in the 21st century despite the many strategies implemented by the government to address the challenges in the sector. This study seeks: to determine the level of "burnout" among nurses at the Spanish Town Hospital, St. Catherine, Jamaica; to ascertain the factors contributing to "burnout" among nurses at the Spanish Town Hospital, St. Catherine, Jamaica; to evaluate whether burnout impact on attitude to work among nurses at the Spanish Town Hospital, St. Catherine, Jamaica. In this section, a discussion of the literature with that of the current empirical findings in an effort to establish the 'burnout' phenomenon among nursing health-care professionals at Spanish Town hospital. In addition to the aforementioned fact, this section of the research provides recommendations, implications of the findings.

The discussion of nursing health-care professional rate of 'burnout' must be contextualized with the large issue of challenges undergoing by the health sector. These challenges are encapsulated in Powell, Bourne and Waller's empirical findings that reveal the general state of health-care in Jamaica as viewed by Jamaicans. The fact is, 9 out of every 50 Jamaicans indicated that health-care is a national problem and this speaks to the wider perspective of health-care dilemma as well as the internal issues that have materialized into the public's reality. One of the internal issues in the health-care sector that has materialized itself into public domain is the turnover of healthcare professionals in Jamaica, especially nursing staffers. In 2014 the Minister of Health, Dr. Fenton Ferguson, Jamaica Observer, opined that the public health care system still had a shortfall of those in the sciences including nurses. Furthermore, the braindrain phenomenon continues to plague the public health care system. In fact, in 2015 , the public health care system in Jamaica 
lost 200 nurses to international migration Jamaica Observer and this adds to the shortfall of public health care professionals in the system. Those facts summarize and emphasize the burden placed on the current cadre of health-care professionals in the public health-care system, and accounts for the high dissatisfaction among the public of the service deliveries in the sector.

The literature has provide evidence that the 'burnout' phenomenon is not atypical to Jamaica Patrick and Lavery, Azeem, Nazir, Zaidi and Akhtar Jennings as well as outside of the health care system. The current work has provide objective evidence that 'burnout' is a reality among nursing professionals at the sole hospital that is in and which serves the parish of St. Catherine, which is the largest human population in Jamaica. Furthermore, using Maslach Burnout Inventory, this study found that that burnout among the nursing staffers was relatively moderate, with personal fulfillment being relatively and emotional exhaustion being moderately high, which is concurring with the literature on stress and burnout in other jurisdictions Jennings, [64,65] Dr. Jennings, a trained nurse, opined that: In 1974, Freuden berger coined the term "burnout" to describe workers' reactions to the chronic stress common in occupations involving numerous direct interactions with people. Burnout is typically conceptualized as a syndrome characterized by emotional exhaustion, depersonalization, and reduced personal accomplishment [66].

Work life, however, is not independent from family life; these domains may even be in conflict. Stress may result from the combined responsibilities of work, marriage, and children [6771]. The effects of both work and non work stress among nurses have been studied infrequently Jennings. And yet, non work stress may be particularly salient to nursing, a predominantly female profession. Women continue to juggle multiple roles, including those roles related to the home and family, for which the women may have sole or major responsibility Jennings p. 2-137 Jennings squarely placed the issue of burnout on the table, particularly among women, and based on the premise of their multi-roles in society to include work and home, which explains the high burnout among female nursing health-care professionals. For this study, the majority of the nursing health-care professionals were females and some base fact would support Jennings' perspective. The current research found that travel to and from work using the public transport system; mothers (on average 2 children); have at least 5 sick-day leave to date; receive 5 hours of sleep on a nightly basis. Using Jennings' perspective, the current facts on nursing health-care professionals at Spanish Town hospital should come as no surprise that their level of emotional exhausting is high as well as depersonalization and therefore account for the low personal accomplishment among this group.

A cross-sectional study of some 180 nurses in Greece by Lahana can be compared with this one as the researchers employed Maslach Inventory scale as is the case for this work.
The comparison of the index for both studies i.e., the current and Lahana work are presented in Table 12, below: Clearly burnout among nurses at Spanish Town hospital, St. Catherine, Jamaica is similar to that which obtains in Greece, suggesting that stress and burnout in the health-care sector is almost the same across different geographic zones (see also, Lasebikan and Oyetunde, Lorenz, Benatti, and Sabino. The burnout phenomenon among nursing is well documented to include theoretical review by Maria, Lasebikan and Oyetunde. While the issue of burnout is high in many jurisdiction, a study in Delhi, India, found the opposite of what obtains in current research as well as one in Turkey [72,73].

The issue of nurses' burnout is not limited to developing nations as in a discussion paper on the American Academy of Medicine website, they wrote: Studies of nurses report a similarly high prevalence of burnout and depression [74]. In a 1999 study of more than 10,000 registered inpatient nurses, 43 percent had high degree of emotional exhaustion [75]. A subsequent study of approximately 68,000 registered nurses in 2007 reported that 35 percent, 37 percent, and 22 percent of hospital nurses, nursing home nurses, and nurses working in other settings had high degree of emotional exhaustion Mc Hugh, et al. [76]. The prevalence of depression may also be higher among nurses than other US workers. In a study of 1,171 registered inpatient nurses, 18 percent had depression versus a national prevalence of approximately 9\% [77]. Less is known about other members of the health care team, although existing data suggest a similar prevalence of burnout among nurse practitioners and physician assistants [78]. The issue of stress resulting from workload is well documented in the literature Selye, Lazarus and Folkman, French and Caplan and the current work concurs with this fact as nursing professionals receive less than 8 hours sleep on a nightly basis, they are mostly mothers and this means additional out of work involvement and these could be accounting for the high emotional exhaustion. In fact, scholars have written on the stressors associated with emotional work Zapf, Vogt, Seifert, Mertini and Isic which offer some insights into the psychological challenges of health care professionals and this goes to the crux of issues experienced by the nursing personnel in this work [7990].

A review of the literature on burnout of nurses or nursing professional has no included issues relating to some of the physical sights of burnout and stress of the job such as frequent headaches, back pain, change in appetite, abnormal weight gain or loss, gastrointestinal disturbances, muscle aches, and tiredness. This study provides self-reported empirical findings on those issues. The majority of the sampled respondents have experienced abnormal weight gain or loss ( $n=143,71.9 \%)$ followed change in appetite $(n=135,67.8 \%)$, muscular aches (48.7\%, $n=97)$, gastrointestinal disturbances $(n=130,64.7 \%)$, with the least indicating 'tiredness' $(n=15,7.5 \%)$. The resultant effect of high stressors placed on nurses has seen increased fatigue, physical illness for example, back pain, frustrations and 
absenteeism among nurses at the Spanish Town Hospital. The high rate of burnout among nursing professionals at the Spanish Town hospital and the physical indicators of this as well as stress are having negative experiences and account for the high rate of turnout. The exodus of nursing professionals from the Spanish Town hospital is captured in the finding that revealed that on average the length of time being employed in their current work is 2.3 years. The behavior to leave or remain in a company is not necessarily those for attitude to work as is well documented in the literature. Attitude to work, therefore, is influenced by socialization (parental influence) and socioeconomic conditions such as social class, income, occupational status and education, which concur with the literature Roe, Roe and Seigelman, Osipow, Tinto, as well as the nature and interpersonal relationships on the job [91-100].

For the current study, when the respondents were asked "I receive social support from my colleagues", "I receive social support from my managers", " and "As a team working together we attend team building sessions", all the responses to those issues were poor or low, suggesting that a part of the challenges experienced by nursing professionals is social dynamics at work. Clearly, the respondents do not feel that they are a part of the work-team and by not being valued; this further goes to make the job somewhat more burdensome, and contribute to the level of emotional frustrations. With this reality coupled with nature of the job, it should come as no surprises that health care professionals at the Spanish Town hospital continue to exit their work in the large numbers and why most of the staffers are relatively new. All of those issues are contributing to the high levels of burnout experienced by nursing professionals in the current study. The issue of high turnover is, therefore, a reality at Spanish Town hospital as it relates to nursing personnel and a part of this is accounted for by distancing of management from junior staffers as well as reluctance of leadership to cater to the wellbeing of the staffers. When the respondents were asked "Stress management is offered at the hospital", "I get recognized for the work I do", "I attend in-service training and workshops to update my knowledge and skills", and "I attend in-service training and workshops to update my knowledge and skills", responses to these indicated poor, suggesting that disconnect between leadership and staffers as it relates to: motivation of staff, understanding the challenges of junior staffers and addressing them, making workers feel a part of the process, working buying into the vision of the institution, and comradery [101-110].

\section{Conclusion}

The phenomenon of 'burnout' is a reality among nursing personnel at the Spanish Town hospital, and it is one that requires urgent attention. The reality is, nursing personnel feels that there is a high degree of depersonalization and that there is gulf between management and themselves, which is affecting their general burnout. Although the issue of burnout is equally the case among nursing personnel in different geo- political areas, managers have sought to ameliorate some of the challenges in an effort to reduce the difficulty of the job. Spanish hospital is hemorrhaging from the low rate of retention among the nursing personnel that must be addressed with urgency, and a part of this solution must rest in provide a coping mechanism for employees to reduce burnout.

\section{Recommendations}

The following recommendations emanate from the current study:

a) The Board of Governors of the hospital (i.e., Spanish Town) should conduct a job satisfaction survey to ascertain the percentage of dissatisfied or satisfied workers as this would provide critical empirical findings that can aid in determining future job separation, particularly because of the low rate of retention among nursing personnel.

b) Workers should be brought into the decision-making process of the hospital by way of an all-inclusive leadership style as this would create an atmosphere of owning things and thereby reduce depersonalization.

c) Introduce rest periods for nursing personnel as well as periodic counseling as these will aid in lower fatigue and burnout.

d) Implement a worker-suggestion box and information there used in decision-making;

e) Introduce a staff development scheme where workers are: awarded scholarships for study; send workers to workshops including customer service; job performance; and how to deal with fatigue; offer internal certifications that can be use at tertiary institution for credits.

f) Implement regular staff-social including management as this would allow for bonding among staffers, understanding each other as well as family outings.

g) Introduce an incentive scheme where workers are: lauded for desired behavior such as customer service; award monthly performance; single-out employees whose children have excelled in academic a work token as well as place the children on the staff notice board.

\section{References}

1. Jamaica Observer (2013) Police take back Spanish Town, Murders down, gangs in retreat: Residents happy, want police to stay in Spanish Town communities. Kingston: Jamaica Observer, Caribbean.

2. Black C (1960) The Old Capital. Spanish Town: Parish Council of St. Catherine.

3. Sherlock P, Campbell H (1998) The Story of the Jamaican People. Kingston: Ian Randle Publishers, Caribbean.

4. Jamaica Gleaner (2015) Fixing health: The brain drain of our health professionals. Kingston: Jamaica Gleaner, Caribbean.

5. Morgan H (2016) Murder problem bigger than police. Kingston: Jamaica Observer, Caribbean. 


\section{Juniper Online Journal of Public Health}

6. Bourne PA, Eldemire-Shearer D (2009) Public hospital health care utilization in Jamaica. Australian Journal of Basic and Applied Sciences 3(4): 3067-3080.

7. Bourne PA (2009) Inflation, public health care and utilization in Jamaica. Australian Journal of Basic and Applied Sciences 3(3): 30083024.

8. Bourne PA (2009) Health inequality in Jamaica, 1988-2007. Australian Journal of Basic and Applied Sciences 3(3): 3040-3052.

9. Bourne PA, Eldemire Shearer D, Paul TJ, La Grenade J, Charles CAD (2010) Public and private health care utilization in differences between socioeconomic strata in Jamaica. Patient Related Outcome Measure 1: 81-91.

10. Jamaica Observer (2015) Public health sector lost 200 nurses last year-NAJ Kingston: Jamaica Observer, Caribbean.

11. Jamaica Observer (2016) NAJ [Nurses Association of Jamaica] seeks government intervention to curb migration of nurses. Kingston: Jamaica Observer, Caribbean.

12. Jamaica Gleaner (2016) Police monitoring Spanish Town as tension brews among gangs. Kingston: Jamaica Gleaner, Caribbean.

13. Porter R (2015) Public sector lost 200 nurses last years: NAJ. Kingston: Jamaica Observer, Caribbean.

14. Salmon ME, Yan J, Hewitt H, Guisinger V (2007) Managed Migration: The Caribbean Approach to Addressing Nursing Services Capacity. Health Research and Educational Trust 42(3): 1354-1372.

15. Carmen C, Bench NS (2015) The Health Workforce in Latin America and the Caribbean. An Analysis of Colombia, Costa Rica, Jamaica, Panama, Peru, and Uruguay 1(1).

16. Haye W De La, Alexis S (2012) The impact of a no-user-fee policy on the quality of patient care/service delivery in Jamaica. West Indian med J 61(2): 168-173.

17. World Health Organization (WHO) (2013) Jamaica: Country Corporate Strategy at a Glance.

18. Brown P (2003) The health service brain drain: What are the options for change? Immunization Focus p. 6-8.

19. Buchan J, Dovlo D (2004) International recruitment of health workers. A report for DFID. Department for International Development, DFID Health Systems Resource Centre, London, United Kingdom.

20. Buchan J, Sochalski J (2004) The migration of nurses: Trends and policies. Bulletin of the World Health Organization 82(8): 587-594.

21. Buchan J, Parkin T, Sochalski J (2003) International nurse mobility: Trends and policy implications. Report funded by Royal College of Nursing, World Health Organization and International Council of Nurses. Geneva, WHO.

22. Lewis M (2005) Ministry of Health Jamaica National Strategic Plan 2006 to 2010. Kingston: Jamaica Ministry of Health.

23. Reynolds-Baker (2013) A Government steadfast with plans to improve health sector. Kingston: Jamaica Information Service.

24. Jamaica Observer (2014) Ferguson: Jamaica's health-care system has space for more science graduates. Kingston: Jamaica Observer.

25. Lofter AK (2012) The "brain drain" of health care workers: causes, solutions and the example of Jamaica. Can J Public Health 103(5): e376-e378.

26. Murphy GT, MacKenzie A, Guy-Walker J, Walker C (2014) Needs-based human resources for health planning in Jamaica: using simulation modeling to inform policy options for pharmacists in the public sector. Human Resources for Health 12: 67
27. Patrick K, Lavery JF (2007) Burnout in nursing. Australian Journal of Advanced Nursing 24(3): 43-48.

28. Azeem SM, Nazir NA, Zaidi ZBA, Akhtar N (2014) Role of Stress and Burnout among Nurses in the Private Hospitals. International Journal of Academic Research in Business and Social Sciences 4(3): 420-428.

29. Jennings BM (2012) Work Stress and Burnout among Nurses: Role of the Work Environment and Working Conditions. Patient Safety and Quality: An Evidence-Based Handbook for Nurses 2(2): 137-158.

30. Poghosyan L, Clarke SP, Finlayson M, Aiken LH (2010) Nurse Burnout and Quality of Care: Cross-National Investigation in Six Countries. National Institutes of health 33(4): 288-298.

31. Lasebikan VO, Oyetunde MO (2012) Burnout among Nurses in a Nigerian General Hospital: Prevalence and Associated Factors. Nursing p. 1-6.

32. Bakker AB, Demerouti E, Sanz-Vergel AI (2014) Burnout and work engagement: The JD-R approach. Annual Review of Organizational Psychology and Organizational Behavior 1: 389-411.

33. Leiter MP, Bakker AB, Maslach C (2014) Burnout at work: A psychological perspective. Hove, Sussex: Psychology Press.

34. Maslach C, Schaufeli WB, Leiter MP (2001) Job burnout. Annual Review of Psychology 52: 397-422.

35. Bakker AB, Le Blanc PM, Schaufeli WB (2005) Burnout contagion among nurses who work at intensive care units. Journal of Advanced Nursing 51(3): 276-287.

36. Maslach C and Jackson S (1983) The measurement of experienced burnout.

37. Maslach C, Schaufeli WB, Leiter MP (2001) Job burnout. Annual Review of Psychology 52(1): 397-442.

38. Maslach C and Jackson S (1984) Burnout in organizational settings. Applied social psychology annual 5: 133-153.

39. Selye H (1956) The stress of life. Mc Graw Hill, New York, USA.

40. Lazarus RS, Folkman S (1884) Stress appraisal and coping. New York, USA

41. French JRP, Caplan RD (1972) Organizational stress and individual strain. In Marrow AJ (edn.); The failure of success. New York, USA, pp. 30-66.

42.Zapf D, Vogt C, Seifert C, Mertini H, Isic A (1999) Emotion work as a source of stress: The concept and development of an instrument. European Journal of Work and Organizational Psychology 8: 371-400.

43. Lorenz VR, Benatti MCC, Sabino MO (2010) Burnout and Stress among Nurses in a University Tertiary Hospital. Revista Latino-Americana de Enfermagem 18(6): 1084-1091

44. Rushton CH, Batcheller J, Schroeder K, Donohue P (2015) Burnout and resilience among nurses practicing in high-intensity settings. American Journal of Critical Care 24(5): 412- 420.

45. Y Parboteeah, KP Shim (2007) The relationship between perceived compensation, organizational commitment and job satisfaction: the case of Mexican workers in the Korean Maquiladoras. International Journal of Human Resource Management 18(10): 1768-1781.

46. Steel R (2002) Turnover theory at the empirical interface: problem of fit and function. Academy of Management Journal 27(3): 346-360.

47. Griffith R, Hom P, Gaertner S (2000) A meta-analysis of antecedents and correlates of employee turnover: update, moderator tests, and research implications for the millennium. Journal of Management 26(3): 463-488 
48. Mobley WH, Griffeth RW, Meglino BM (1979) Review and conceptual analysis of employee turnover process. Psychological Bulletin 86(3): 493-522.

49. Meyer JP, Allen NJ (1997) Commitment in the workplace: theory, research and application. Thousand Oaks, Canada, USA.

50. Roe A (1957) Early Determinants of Occupational Choice. Journal of Counseling Psychology 4: 212-217.

51. Roe A, Seigelman M (1964) The Origin of Interests. The SPGS Inquiry Series. American Personnel and Guidance Association, Washington, USA.

52. Tinto V (1984) Patterns of Educational Sponsorship to Work. Work and Occupations 11(3): 309-30.

53. Freudenberger HJ (1974) Staff burn-out. J Social Issues 30(1): 159-85.

54. Maria N (2012) Burnout among staff nurses: Examining the causes, coping strategies and prevention. Bachelor of Science thesis.

55. Leiter MP, Maslach C (2009) Nurse turnover: the mediating role of burnout. Journal of Nursing Management 17(3): 331-339.

56. Cimiotti JP, Aiken LH, Sloane DM, Wu ES (2012) Nurse staffing, burnout, and health care associated infection 40(6): 486-490.

57. Crotty M (2005) The foundations of social research: Meaning and perspective in the research process. London, United Kingdom.

58. Zeytinoglu IU, Denton M, Davies S, Plenderleith Millen J (2009) Casual zed employment and turnover intention: Home care workers in Ontario, Health Policy, Canada, United Kingdom, 91(3): 258-268.

59. Cook AL (2008) Job satisfaction and job performance: Is the relationship spurious.Unpublished Master of Science thesis, Texas A and M University, Texas, USA.

60. Balashov Yuri, Rosenberg Alex (2002) Introduction. In Philosophy of Science: Contemporary readings by Balashov, Yuri, and Alex Rosenberg, London, United Kingdom p. 3-7.

61. Kuhn TS (1996) The structure of scientific revolutions ( $3^{\text {rd }}$ edn.); Chicago, The University of Chicago Press, USA.

62. Weirsman W (2000) Research methods in Education, An Introduction, Massachusetts. Allyn and Bacon pp. 504.

63. Powell LA, Bourne P, Waller L (2007) Probing Jamaica's Political culture, Main trends in the July-August 2006 leadership and governance survey. Kingston: Centre for leadership and governance, Department of Government, the University of the West Indies.

64. Jennings BM (2008) Work Stress and Burnout among Nurses: Role of the Work Environment and Working Conditions. In Hughes RG, (Ed.). Patient Safety and Quality: An Evidence-Based Handbook for Nurses, Rockville (MD): Agency for Healthcare Research and Quality, USA.

65. Lahana E, Papadopoulou K, Roumeliotou O, Tsounis A, Sarafis P, et al. (2017) Burnout among nurses working in social welfare centers for the disabled. BMC Nursing 16:15.

66. Maslach C, Jackson S (1982) Burnout in health professions: A social psychological analysis. pp. 79-103.

67. Near JP, Rice RW, Hunt RG (1980) The relationship between work and non work domains: a review of empirical research Acad Manage Rev 5(3): 415-29.

68. Pearlin LI (1983) Role strains and personal stress. In: Kaplan HB, editor. Psychological stress Trends in theory and research. Academic Press, New York, USA pp. 3-32.

69. Haw MA (1982) Women, work and stress: A review and agenda for the future. J Health Soc Behav 23(2): 132-144.

70. Muller C (1986) Health and health care of employed adults: occupation and gender. Women Health 11(1): 27-45.
71. Woods NF (1985) Employment, family roles, and mental ill health in young married women. Nurs Res 34: 4-10.

72. Negi Y, Bagga R (2015) Burnout among nursing professionals in Tertiary care hospitals of Delhi. Journal of Health Management 17(2): 163-177.

73. Statistical Institute of Jamaica (STATIN) (2013) Population.

74. Dyrbye LN, Shanafelt TD, Sinsky C, Cipriano PF, Bhatt J, et al. (2017) Burnout among health care professionals: A call to explore and address this under recognized threat to safe, high-quality care. American Academy of Medicine.

75. Aiken LH, Clarke SP, Sloane DM, Sochalski J, Silber JH (2002) Hospital nurse staffing and patient mortality, nurse burnout, and job dissatisfaction. JAMA 288(16):1987-93.

76. McHugh MD, Kutney-Lee A, Cimiotti JP, Sloane DM, Aiken LH (2011) Nurses' widespread job dissatisfaction, burnout, and frustration with health benefits signal problems for patient care. Health Aff 30: 202210 .

77. Letvak SA, Ruhm CJ, Gupta SN (2012) Nurses' presenters and its effects on self-reported quality of care and costs. Am J Nurs 112(2): 30-38.

78. Benson MA, Peterson T, Salazar L, Morris W, Hall R, et al. (2016) Burnout in rural physician assistants: An initial study. J Physician Assist Educ 27(2): 81-83.

79. Babbie E (2007) The practice of social research (10 $0^{\text {th }}$ Edn.); Wadsworth, Rout ledge, London, UK.

80. Berg B (2001) Qualitative Research Methods for the social sciences. ( $4^{\text {th }}$ edn.); Allyn and Beacon, USA.

81. Blalock HM (1971) Causal models in the social sciences. Chicago: Aldine-Atherton.

82. Blalock HM (1964) Causal inferences in non-experimental research. Chapel Hill: University of North Carolina Press 44(4): 584-586.

83. Boxill I, Chambers C, Wint E (1997) Introduction to social research with applications to the Caribbean. Kingston, Jamaica: Canoe Press/ University of the West Indies.

84. Bryman A, Cramer D (2005) Quantitative data analysis with SPSS with 12 and 13: A guide for social scientists. Rout ledge, London, UK.

85. Buisseret D (1996) Historic Jamaica from the air. Kingston: Ian Randle Publishers.

86. Creswell JW (2013) Qualitative inquiry and research design: Choosing among five approaches. Thousand Oaks, CA: Sage Publications.

87. Jamaica Gleaner (2008) Cuba to assist with nurse shortage. Kingston: Jamaica Gleaner, Caribbean.

88. Jamaica Gleaner (2008) Cuba to assist with nurse shortage. Kingston: Jamaica Gleaner, Caribbean.

89. Kish L (1965) Survey sampling. John Wiley and Son, New York, USA.

90. Love Jamaica (2015) Gang wars intensify in Spanish Town, “Donkey” killed.

91. Paulin D (2002) Nurses heading north for better-paying jobs. Kingston: Jamaica Observer, caribbean.

92. Places and Spaces Magazine (2014) Spanish Town: From Capital City to Near Chaos.

93. Rea LM, Parker RA (2005) Designing and conducting survey research: A comprehensive guide, ( $3^{\text {rd }}$ edn.); San Francisco: Jossey-Bass, USA.

94. Robinson C (2010) Pastor among 2 killed in Spanish Town gang feud. Kingston: Jamaica Observer, Caribbean.

95. Robinson C (2010) Two dead in Spanish Town gang war. Kingston: Jamaica Observer, Caribbean. 
96. Robinson C (2010) Another deadly gang forms in Spanish Town: Police concerned about emergence of 'No Order' group. Kingston: Jamaica Observer, Caribbean.

97. Schlick M (1979) Philosophical Paper HL Mulder and BEB. Vande, Velde-Schlick Dordrecht: Reidel 2: 210-224.

98. Smith M (1998) Social Science in Question. London: Open University Press/Sage, pp. 161-166.

99. Turner R, McLeod D (ud). Thug's battle for gang control: Six killed in internal conflict. Kingston: Jamaica Star, Caribbean.

100. University of Leicester (2011) Research methods. Leicester: University of Leicester.

101. Walters B (2015) Silent night in several Spanish Town communities. Kingston: Jamaica Observer, Caribbean.

102. Weber M (1949) The methodology of the social sciences, trans. New York, USA.

103. Weber M (1974) Subjectivity and determinism. In positivism and sociology by Giddens A, London: Heinemann 23-32.

104. Weber M (1981) Some categories of interpretative sociology. Sociological Quarterly 22(2): 151-180.
105. Alparslan O, Doganer G (2009) Relationship between levels of burnout of midwives who work in Sivas, Turkey province center and identified socio-demographic characteristics. International Journal of Nursing and Midwifery 1(2): 019-028.

106. Jennings BM (1990) Stress, locus of control, social support, and psychological symptoms among head nurses. Res Nurs Health 13(6): 393-401.

107. Maria N (2012) Burnout among staff nurses. Examining the causes, coping strategies and prevention. Bachelor of Nursing, Arcada Department of Health and Social Work.

108. Lorenz VR, Benatti MCG, Sabino MO (2010) Burnout and stress among nurses in a University tertiary hospital. Rev. Latino-Am. Enfermagem 18(6): 1084-1091.

109. Lorenz VR, Benatti MCG, Sabino MO (2010) Burnout and stress among nurses in a University tertiary hospital. Rev. Latino-Am. Enfermagem 18(6): 1084-1091.

110. Lasebikan VO, Oyetunde MO (2012) Burnout among Nigerian general hospital: Prevalence and associated factors. International Scholarly.

\section{Your next submission with Juniper Publishers will reach you the below assets}

- Quality Editorial service

- Swift Peer Review

- Reprints availability

- E-prints Service

- Manuscript Podcast for convenient understanding

- Global attainment for your research

- Manuscript accessibility in different formats

( Pdf, E-pub, Full Text, Audio)

- Unceasing customer service

Track the below URL for one-step submission https://juniperpublishers.com/online-submission.php 